\title{
Microbiome impact on metabolism and function of sex, thyroid, growth and parathyroid hormones
}

\author{
Michał Kunc ${ }^{1}$, Anna Gabrych¹ and Jacek M. Witkowski² ${ }^{\bowtie}$ \\ ${ }^{1}$ Faculty of Medicine and 2Department of Pathophysiology, Medical University of Gdańsk, Gdańsk, Poland
}

\begin{abstract}
Commensal bacteria and their genes associated with host are known as microbiome. In recent years, microbial influence on host endocrine system has been under detailed investigation. The role of microbiome in the pathogenesis of insulin resistance and obesity, the function of hypothalamic-pituitary-adrenal axis and secretion of hormones regulating appetite is well described in world literature. In this article we discuss poorly reviewed issues: the microbiome role in modulation of non-peptide (sex and thyroid) and peptide (growth hormone and parathyroid hormone) functions. Understanding complex bidirectional relations between host endocrine system and bacteria is of fundamental importance to understanding microbial impact on host reproduction, risk of endocrine-related cancers, pathogenesis of non-thyroidal illness syndrome, growth failure in children and hormonal changes during chronic kidney disease. This article also highlights effects of dietary compounds on microbiome composition and bacterial enzymes activity, and thus host hormonal status.
\end{abstract}

Key words: microbiome, lipopolysaccharide, estrogens, thyroid hormones, growth hormone

Received: 30 June, 2015; revised: 21 September, 2015; accepted: 25 September, 2015; available on-line: 26 October, 2015

\section{INTRODUCTION}

By definition microbiome is the catalog of commensal bacteria (microbiota) and their genes associated with host (Ursell et al., 2012). Human microbiome is strongly associated with the number of processes, which occur in host organism, affecting its immunological, nutritional and metabolic functions. That is why in recent years the conception of human-microbiome superorganism was proposed (Dietert \& Dietert, 2012). The microbial composition is established in early life and is mainly dependent on mode of delivery and diet. After infancy the main factors which affect microbiome are diet, antibiotic treatment, obesity, sex and geography. There are complex bidirectional relations between host-endocrine system and bacteria, which justifies the use of term "human-microbiome superorganism" also in hormonal system. Microbes sense and react for example to host adrenaline, noradrenaline, triiodothyronine and sex hormones, which changes their metabolism, growth and virulence (Sperandio et al., 2003; Hughes \& Sperandio, 2008; García-Gómez et al., 2013). In turn, many reviews and original papers analyzing the influence of microbiota on hormones regulating appetite, insulin sensitivity, pathogenesis of diabetes and obesity and hypothalamic- pituitary-adrenal axis have been published (Sudo et al., 2004; Gao et al., 2009; Vrieze et al., 2010; Burcelin et al., 2011; Zimomra et al., 2011; Holzer et al., 2012; Norris et al., 2013). In this review, we focus on less well described issues: the microbiome role in modulation of non-peptide (sex and thyroid) and peptide (growth hormone $\mathrm{GH}$ and parathyroid hormone - PTH) functions.

In animals, bacteria influence their endocrine system via various mechanism, i.e. intestinal metabolism of bile-excreted hormones, intestinal conversion of exogenous molecules to endocrine-active derivatives, production/release of endocrine-active molecules like short chain fatty acids (SCFAs) and lipopolysaccharide (LPS). The first way concerns steroid and thyroid hormones, which are metabolized in the liver and excreted with bile. A large number of intestine bacteria are capable of hydrolysis of hormone conjugates and afterward modify chemical structure of free molecules. Another important aspect concerns the ability of microorganisms associated with plants to produce phytohormones and hormone-like substances, which may modify host metabolism (Tsavkelova et al., 2006).

\section{SEX HORMONES AND REPRODUCTION}

Steroid sex hormones such as estradiol (E2), testosterone $(\mathrm{T})$ and progesterone (P4) modulate a number of physiological processes, both related and unrelated to reproduction. They are produced in endocrine glands such as adrenal cortex, ovaries and testes as well as in peripheral tissues like skin. They act through intracellular and extracellular receptors and affect e.g. host blood pressure, energy homeostasis and metabolism, bone remodeling, mood, erythropoiesis and cells growth. Then they are metabolized in the liver and excreted with the bile. Thus, liver metabolism of steroid hormones includes: reduction of the sterol ring $A$, conjugation with sulfate or glucuronide, and excretion in the bile. Afterward these compounds are deconjugated by bacterial sulfatases (Van Eldere et al., 1988) and glucuronidases synthesized both in the intestinal wall and by bacteria (Macdonald et al., 1983). Moreover steroids undergo enterohepatic circulation (EHC).

Large number of species found in human intestinal or other microbiomes, such as Eubacterium lentum, Bac-

e-mail: jawit@gumed.edu.pl

Abbreviations: E2, estradiol; EHC, enterohepatic circulation; GH, growth hormone; hCG, human chorionic gonadotropin ; hPL, human placental lactogen ; HSD, hydroxysteroid dehydrogenase; IL, interleukin; LBP, LPS-binding protein; LPS, lipopolysaccharide; P4, progesterone; PAH, polycyclic aromatic hydrocarbons; $\mathrm{PTH}$, parathyroid hormone; SCFA, short chain fatty acid; T, testosterone; TLR, Toll-like receptor 
teroides sp., Bifidobacterium sp., Streptococcus sp. posses enzymes which are involved in degradation of unconjugated steroids, like 21-dehydroxylase, 17,20-desmolase, 16-dehydratase and various dehydrogenases (Macdonald et al., 1983). Interestingly, hydroxysteroid dehydrogenases (HSDs) which are involved in the production of steroid hormones and regulation of their receptor-active and receptor-inactive derivative levels in host cells, were found in bacteria. Accumulating evidence indicates that members of the normal human gastro-intestinal flora (especially members of Actinobacteria, Proteobacteria and Firmicutes), possess HSDs, which are active on keto- or hydroxyl-groups at positions C3, 7, 12, 17 and 20 of steroid compounds (Kisiela et al., 2012). It follows that bacterial HSDs may influence concentration of active steroid derivatives which return to blood throughout EHC. Furthermore, bacterial steroid metabolism has its local long-term effects, since it is known that increased number of bacterial strains capable of steroid degradation in colon is associated with higher risk of colon cancer (Debas, 1981).

Except of direct metabolism of steroid hormones, bacteria may change expression of host genes involved in steroid hormones metabolism and function. Some studies highlight the effects of oral probiotic supplementation on sex hormones metabolism and function. Research conducted on female zebrafish fed with Lactobacillus rhamnosus revealed an increase of transcription of aromatase cytochrome p 19 (cyp19a), vitellogenin (vtg), $\alpha$ isoform of the estrogen receptor (er $\alpha$ ), luteinizing hormone receptor (lhr), 20- $\beta$ hydroxysteroid dehydrogenase (20 $\beta$-hsd), membrane progesterone receptors $\alpha$ and $\beta$ and activin $\beta$ A1 genes. These changes of respective genes' expression affect sex differentiation during larval development and improve fertility in adults (Carnevali et al., 2013). In turn metabolomic analysis with use of murine typhoid infection model revealed that during Salmonella typhimurium infection the $3 \beta-H S D 2$ and $17 \beta-H S D 2$ gene expression in the liver is repressed (Antunes et al., 2011). During acute shigellosis in human volunteers, significant reduction in fecal steroid metabolites was observed (Huang et al., 1976). Changes in steroid metabolism during infection may diminish the HPA axis function and thus hinder proper reaction to pathogen invasion.

\section{LPS-DEPENDENT EFFECTS}

Not to be underestimated is bacterial impact on host steroid hormone metabolism and function which is exerted via LPS (endotoxin). LPS is a part of Gram-negative bacteria cell wall and is a trigger of septic shock. Nevertheless, Marshall stated that LPS is "not less an endotoxin than an exohormone" (Marshall, 2005). He pointed out some LPS features similar to human hormones: 1. its exposure arises from endogenous stores (commensal, Gram-negative bacteria of the gastrointestinal tract), 2. it has a dedicated carrier protein, 3. it interacts with specific cellular receptor, 4. its signaling is specifically modulated by endogenous mechanisms and in turn LPS downstream signal interferes with endogenous hormones pathways. Endotoxemia and thus increased LPS influence on host occur under various conditions, such as major vascular surgery (Roumen et al., 1993), cigarette smoking (Hasday et al., 1999), mechanical ventilation (Nahum et al., 1997), laparoscopic abdominal surgery (Schietroma et al., 2006, 2013), colorectal carcinoma (Iarŭmov et al., 2004), high-fat diet (Erridge et al., 2007), inflammatory bowel disease (Aoki, 1978), inten- sive care (Guidet et al., 1994), stomatological intervention and tooth-brushing (Jacob et al., 2012). Increased translocation of LPS in leaky gut syndrome may cause chronic dysfunction of some elements of endocrine and other systems (Maes et al., 2008). LPS is composed of three parts: lipid A, a core oligosaccharide, and an $\mathrm{O}$ side chain (Pålsson-McDermott \& O'Neill, 2004). In bloodstream LPS is recognized by LPS-binding protein (LBP), an acute phase protein produced in the liver. Afterward, LBP facilitates LPS binding to CD14, which enables transfer of LPS to the TLR4/MD-2 receptor complex. LPS causes TLR4/MD-2 homodimerization, thus aids interactions between intracellular domains of TLR-4 and Toll/IL-1R (TIR) domains of adaptor proteins. Subsequent signals activated by TLR4 have been divided into MyD88-dependent and MyD88-independent (TRIFdependent) pathways. MyD88-dependent pathway leads to the activation of IRAKs/TRAF6 and in consequence NF- $x$ B, AP-1 and IRF-5 transcription factors. In turn TRIF signals recruit TRAF3 and RIP1, thus induce Type I interferons by activation of IRF3, NF- $x$ B and AP-1.

Signaling pathways of human hormones are regulated by various negative feedback loops. Similarly, LPS action is inhibited by circulating inhibitors and factors causing acceleration of LPS degradation, inhibition of TLR4 signaling or enhancement of TLR4 degradation (Lu et al., 2008).

LPS intravenous injection activates HPA and leads to increased secretion of CRH and AVP into hypophyseal portal blood (HPB), which is mediated by EP1 and EP3 pathway activation in periventricular nucleus (PVN) (Dadoun et al., 1998; Matsuoka et al., 2003). This effect was even observed in tilapia, which may reflects evolutionary preservation of hypothalamic response to LPS (Pepels et al., 2004). Simultaneously, LPS suppresses $\mathrm{GnRH}$ pulsatile release into HPB and indirectly LH concentrations and pulse amplitude thus inhibits reproduction (Battaglia et al., 1997, 1998). LPS elevates the E2/P4 ratio and alters the function of FSHR and LHR in uterus during the preimplantation days of pregnancy in mouse leading to the failure of implantation (Agrawal et al., 2011, 2012). Furthermore, after implantation LPS decreases placental endocrine function, reducing amounts of trophoblast-released human chorionic gonadotropin ( $\mathrm{hCG}$ ), human placental lactogen (hPL), and P4 and hence leading to preterm delivery (Okada et al., 1997). LPS is known to be a direct suppressor of E2 secretion by ovarian granulosa cells in bovine, which could explain a mechanism of infertility in pelvic inflammatory disease (Williams et al., 2008). Ovarian follicles do not contain immune cells, however granulosa cells express the TLR4 and via this receptor LPS down-regulates transcripts for aromatase (Herath et al., 2007). Similar effects were observed after primary bovine granulosa cells exposure to the Pam3CSK4 and peptidoglycan that bind TLR2 (Shimizu et al., 1998; Price et al., 2013). LPS or peptidoglycan treatment of theca cells under LH exposure results in suppressed P4 and androstenedione (A4) production (Magata et al., $2014 b, 2014 a)$. It follows that in cows uterine infections may lead to ovarian dysfunction. In humans, high expression of TLR1, 2, 4, 5, 6 and COX2 gene in follicular cells was observed in patients with poor ovarian response to gonadotropin stimulation (Taghavi et al., 2014). It suggests that increased TLR pathways activity may be associated with declining fertility rates.

Testicular functions, both spermatogenesis and steroidogenesis, are also disrupted after LPS treatment. Leydig cells (LC) and Sertoli cells (SC) — the key 
players in the hormonal function of testes - express TLR-2 and TLR-4, similarly as testicular macrophages (Winnall et al., 2011). In the response to LPS, these latter cells start to produce reactive oxygen species (ROS) and nitric oxide, which alter the function of LC mitochondria (Pomerantz \& Pitelka, 1998; Allen et al., 2004). Furthermore, LPS increases NF- $x$ B pathway activity in LC, hence reducing testicular Cyp11a, StAR and $3 \beta-H S D$ protein levels. In consequence, plasma $\mathrm{T}$ level decreases. This effect is partially dependent on LH secretion reduction and inflammatory cytokine level elevation caused by LPS. In SC, LPS acts via MyD88 pathway and activates expression of IL1, IL6 and activin A. In turn, FSH increases cAMP level and promotes lactate, transferrin, stem cell factor (SCF) and inhibin B expression. Intriguingly, these two pathways have probably reciprocal inhibitory effects (Hedger, 2011). It is well established that acute and chronic bacterial infections may be associated with temporary or constant infertility. Vitamin $\mathrm{K}$ may contribute to inhibition of inflammatory pathways in testis and may help maintain steady levels of $\mathrm{T}$ ( $\mathrm{Ta}$ kumi et al., 2011).

\section{NON-LPS-DEPENDENT EFFECTS}

\section{Estrogens}

Apart from LPS-dependent influence on estrogen function, bacteria may also directly metabolize them and similar particles, like phytoestrogens. To better understand these processess we describe host estrogen metabolism first.

Before excretion with bile, estrogens are metabolized in several steps in the liver (Fig. 1). First of all, interconvertible primary estrogens estrone (E1) and estradiol (E2) are hydroxylated by cytochrome P450 enzymes, yielding catechol estrogens: either 2-hydroxy (2-OH) or 4-hydroxy (4-OH) metabolites. Another derivative is made by hydroxylation at C-16 $\alpha$ position yielding $16 \alpha$-hydroxy $(16 \alpha-\mathrm{OH})$ derivative. Both $16 \alpha-\mathrm{OH}$ and produced in small portion 4-OH derivatives have greater estrogenic activity compared to $2-\mathrm{OH}$, thus domination of $\mathrm{C}-16 \alpha$ pathway has been hypothesized as a potential risk factor of breast cancer. However, recent studies do not support this hypothesis (Eliassen et al., 2008). Catechol estrogens might be oxidized into harmful derivatives- quinones-

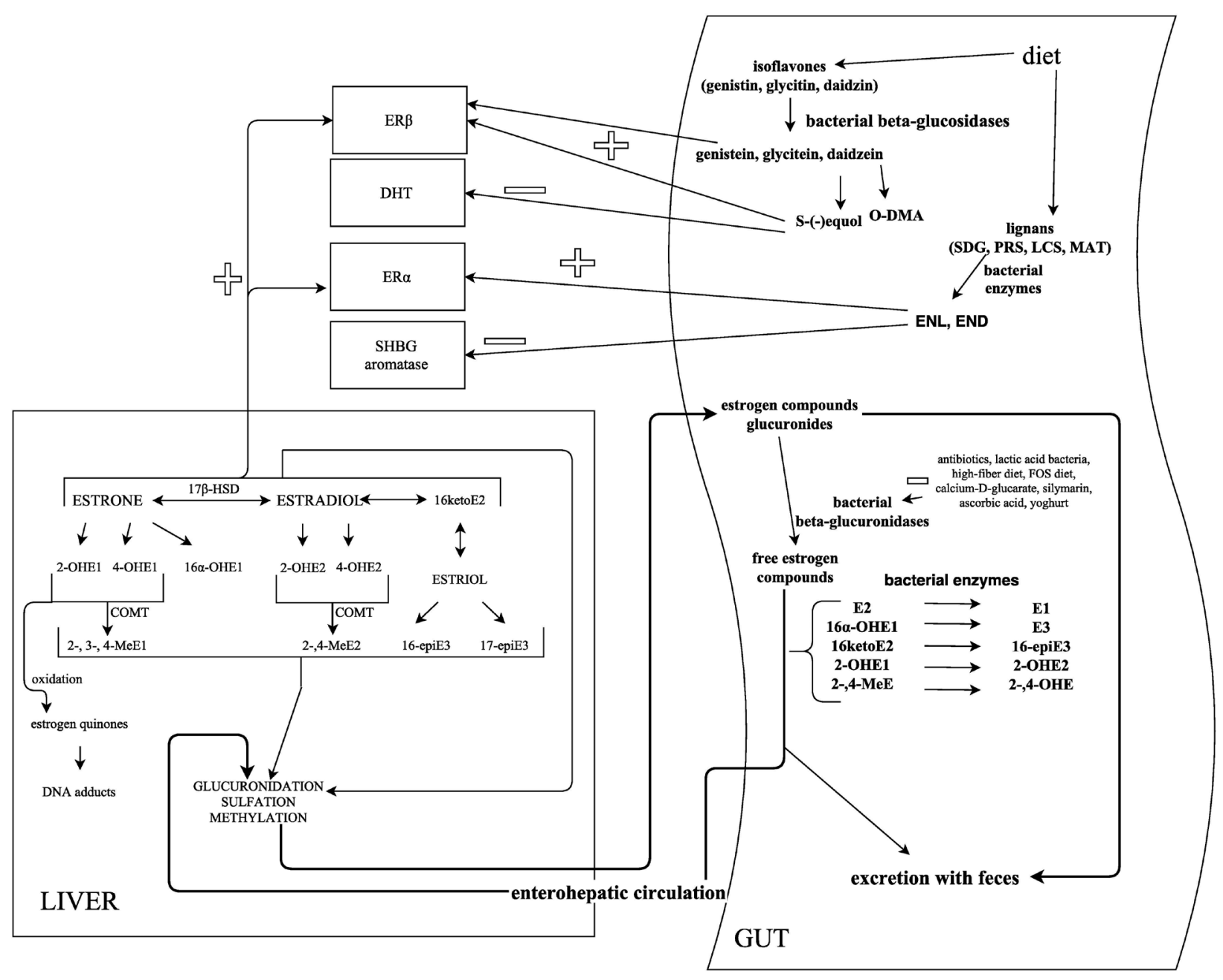

Figure 1. Metabolism of estrogens and estrogenic compounds.

The bold font denotes the metabolic pathways dependent on bacterial activity. Details, see main text. COMT, catechol-O-methyl transferase; DHT, dihydrotestosterone; ER, estrogen receptor; E, estrogens; E1, estrone; E2, estradiol; E3, estriol; FOS, fructooligosaccharides; LCS, lariciresinol; MAT, matairesinol; O-DMA, O-desmethylangolensin; PRS, pinoresinol; SDG, secoisolariciresinol diglucoside; SHBG, sex hormone binding protein 
that can react with DNA to form depurinating adducts, thus are potential breast cancer initiatiors (Cavalieri et al., 2006). Methylation of $2-\mathrm{OH}$ and $4-\mathrm{OH}$ estrogens by catechol-O-methyltransferase (COMT) prevents the formation of estrogen quinones, therefore the metoxy and catechol estrogen proportions may influence the cancer risk. Another metabolic pathway includes E2 conversion to 16-ketoE2 and further epimerization to 16-epi-E3 and 17-epi-E3 (Jobe et al., 2013). This latter steroid is very interesting, since it has an anti-inflammatory, but not glycogenic activity (Latman et al., 1994). The phase II of estrogen metabolism includes either glucuronidation or sulfation or methylation, which facilitates its elimination from the organism via bile in feces and with urine.

Plottel and coworkers proposed the term "estrobolome" to define the aggregate of enteric bacterial genes whose products are capable of metabolizing estrogens (Plottel \& Blaser, 2011). Every individual has its own, unique estrobolome, which influences EHC of estrogens. Bacterial $\beta$-glucuronidases hydrolyze glucuronides which are excreted via bile, thus promotes recycling of aglycone forms through enterohepatic cycle. Excess of $\beta$-glucuronidase activity may be associated with higher estrogen-dependent cancers risk. Most species with $\beta$-glucuronidase expression are members of Firmicutes phylum and Enterobacteriaceae family (Lactobacillus, Streptococcus, Clostridium, Ruminococcus, Roseburia, Faecalibacterium, Eubacterium and Escherichia), however bacteria capable of $\beta$-glucuronidase production are also among Actinobacteria (i.e. Bifidobacterium dentium) (Gloux et al., 2011). Administration of oral oxytetracyclin diminished urinary excretion and increased losses of conjugated estrogen metabolites in feces in men, probably by destruction of $\beta$-glucuronidase-producing microflora and the interruption of the estrogen recycling (Hämäläinen et al., 1987). In one study fecal $\beta$-glucuronidase activity and diversity of fecal microbiome were found to be directly associated with higher concentrations of systemic estrogens (Flores et al., 2012a). Lactic acid bacteria supplements and high-fiber diet (like vegetarian) decrease fecal bacterial $\beta$-glucuronidase, which leads to increased fecal excretion and a decreased plasma concentration of estrogen (Goldin et al., 1980, 1982; Goldin \& Gorbach, 1984; Han et al., 2005). Other factors which diminish $\beta$-glucuronidase activity include oral antibiotic treatment (Hämäläinen et al., 1987), lactic acid bacteria probiotics (Goldin \& Gorbach, 1984), high-fiber diet (Gorbach, 1984), cellulose-fructooligosaccharides (FOS) diet (Gudiel-Urbano \& Goñi, 2002), cabbage and sweet pepper pectin protein complexes (Borisenkov et al., 2011), calcium-D-glucarate (Zółtaszek et al., 2008), silymarin (Kim et al., 1994), ascorbic acid (Young et al., 1990) and yoghurt (de Moreno de LeBlanc \& Perdigón, 2005). In turn bile salts enhance $\beta$-glucuronidase activity (Fujisawa \& Mori, 1996), while weight loss elevates its fecal level (Flores et al., 2012b). Advanced age and childhood are associated with higher $\beta$-glucuronidase activity than middle age, probably due to microflora composition changes throughout life (Goldin \& Gorbach, 1977; Mroczyńska \& Libudzisz, 2010).

In addition to the ability of deconjugation of steroid hormone glucuronides, intestinal bacteria are also able to interconvert steroid derivatives. Alcatigenes faecalis, Pseudomonas aeruginosa, Staphylococcus aureus and Bacteroides fragilis interconvert E2 to E1 and participate in regulation of E2 concentration (Järvenpää et al., 1980). Other reactions performed by intestinal bacteria include: E1 formation from E1-3-sulfate, estriol (E3) from 16 $\alpha$-OHE1, 16-ketoE2 reduction to 16-epiE3 (Macdonald et al., 1983).
Ampicillin treatment diminishes reductive metabolism of estrogens in intestine, thus increases $\mathrm{E} 1 / \mathrm{E} 2$ and $\mathrm{E} 2 / \mathrm{E} 3$ ratio in both urine and feces (Adlercreutz et al., 1984). Catechol estrogens 2-OHE1 and 2-OHE2 are interconverted by human fecal bacteria in anaerobic and aerobic conditions (Järvenpää et al., 1980). Fecal flora is capable of formation of catechol estrogens from metoxyestrogens. It follows that bacteria are able to convert biologically inactive estrogens into active forms (Axelson \& Sjövall, 1983).

Gingival bacteria, similarly to the intestinal ones are capable to metabolize sex hormones (García-Gómez et al., 2013). During the pubertal period gingivitis rate significantly increases and this effect is thought to be related with higher concentration of steroids in saliva, which may be the carbon source for gingivitis-related bacteria as Prevotella intermedia. This species uptakes estrogens and P4, when its important growth factor, vitamin $K$, is unavailable (Kornman \& Loesche, 1982).

Bacterial colonization of germ-free mice led to the normalization of estrous cycles and increase of reproduction, probably due to direct influence on intravaginal epithelial cells and indirect effect via EHC of estrogen metabolites (Shimizu et al., 1998). The bidirectional connection between vaginal microflora and estrous cycle was also the conclusion of other studies (Minami et al., 1987).

Van Wiele et al. showed that colon microbiota are able to bioactivate ingested polycyclic aromatic hydrocarbons (PAHs) like naphthalene, phenanthrene, pyrene, and benzo(a)pyrene to estrogenic hydroxylated metabolites (Van de Wiele et al., 2005). That conversion can exacerbate cancerogenic effect of PAHs and affect endocrine system; nevertheless the real role of estrogenic PAHs is still unclear (Gozgit et al., 2004).

Another group of exogenous molecules with estrogenic activity are plant-derived phytoestrogens. Lignans and isoflavones are the best studied groups of phytoestrogens and are of interest of this article, because their activity is partly dependent on bacteria.

Flaxseeds, sesame seeds, soybean, berries and nuts are known lignan-rich foods. Lignans are classified as phytoestrogens, despite their lack of biological activity per se. Intestinal bacteria in the upper part of the large bowel convert lignans (secoisolariciresinol, pinoresinol, matairesinol, lariciresinol) to compounds with estrogenic activity called enterolignans: enterolacton (ENL) and enterodiol (END). Enterolignans induce the production of sex hormone-binding globulin (SHBG) in the liver and inhibit aromatase activity, therefore reduce the levels of free and total estrogens in circulation (Hall, 2001). Both ENL and END act as ER $\alpha$ agonist, however they have weaker agonist activity than endogenous estrogens (Carreau et al., 2008). When endogenous estrogens level is low, ENL and END increase total systemic estrogenic effect, whereas when estrogens level is high they prevent estrogen from exerting its effects. Flaxseed-derived enterolignans decrease proliferation fraction in prostate cancer (Azrad et al., 2013) and risk of colorectal adenoma (Kuijsten et al., 2006). They may increase survival of postmenopausal breast cancer patients (Buck et al., 2011) and lower risk of $\mathrm{ER}+/ \mathrm{PR}+$ breast cancer (Touillaud et al., 2007). However, other studies did not show associations between enterolignans and lower breast cancer risk (Peeters et al., 2003; Zaineddin et al., 2012). The main lignan, secoisolariciresinol (SECO) and its diglucoside (SDG), pinoresinol (PRS) and lariciresinol (LCS) are converted into enterolignans via multistage route to END, whereas matairesinol undergoes direct conversion to ENL (Wang et al., 2010). END may then be irreversibly converted to ENL. The final ENL 
to END ratio depends on type of food and individual composition of gut microflora (Bartkiene et al., 2011). In one study the subdominance of ENL-producing bacteria in gastrointestinal tract was found (Eeckhaut et al., 2008). High colon concentrations of Peptostreptococcus productus, Eggerthella lenta and Clostridium coccoides, which are able to demethylase and dehydroxylate SECO are associated with higher serum enterolignans level (Clavel et al., 2005). To conclude, microflora composition affects bioavailability of enterolignans and therefore its action.

Human intestinal flora metabolizes also another class of phytoestrogens, isoflavones in similar to lignans way. Fabaceae is the plant family, which members (e.g. soybean) almost exclusively produce isoflavones. Dietary isoflavones occur in the form of glycosides: genistin, daidzin and glycitin, which are bioactivated by bacterial $\beta$-glucosidases in colon to aglycones: genistein, daidzein and glycitein. Daidzein is further metabolized to S-(-)equol and O-desmethylangolensin (O-DMA). Interestingly, not all people are able to produce these derivatives - the first can be found only in $20-60 \%$ (so called "equol-producers") and the latter in $80-90 \%$ of the population (Atkinson et al., 2005). Some studies indicate that ability to produce these metabolites, especially equol, is associated with lower risk of breast and prostate cancer, acne and male-pattern baldness (Lund et al., 2004). Intestine-derived $\mathrm{S}$-(-)equol is a selective ER $\beta$ agonist and antiandrogen. Mechanism of its antiandrogenic effect is associated neither with $5 \alpha$-reductase inhibition nor with binding to androgen receptor, but rather with direct binding to dihydrotestosterone (DHT) (Setchell et al., 2005). Equol non-producers have probably higher risk of some diseases (e.g. prostate cancer) than equol-producers (Akaza, 2012). It was demonstrated that supplementation of equol-producing bacteria may convert non-equol producer into an equol-producer (Decroos et al., 2006). Lactococcus garvieae is used to produce S-(-)equol rich substance, called SE5-OH (Yee et al., 2008). Supplementation with this food ingredient improved mood in perimenopau$\mathrm{sal} /$ postmenopausal equol non-producers (Ishiwata et al., 2009). There are some differences in estrogen metabolism by fecal bacteria between equol-producers and non-producers. The latter are more likely than former to convert E1 to E2, and $16 \alpha-\mathrm{OHE} 1$ to E3 (Atkinson, 2004). Increased E2 and E3 formation may have mutually exclusive effects in evaluation of breast cancer risk.

Interestingly, amongst species capable of soy milk isoflavone bioconversion are lactic acid bacteria which are also potentially able to influence the renin-angiotensin hormonal system (Yeo \& Liong, 2010). These bacteria have special proteolytic enzymes and produce angiotensin-I-converting enzyme (ACE) inhibitory peptides from milk proteins. Inhibitory peptide mixtures are resistant to digestive enzymes and dairy processing (Gobbetti et al., 2000). Significantly lower pressor effect after intravenous angiotensin I injection, was observed in rats which were pre-fed with milk fermented using certain strains of Lactobacillus belveticus (Fuglsang et al., 2003).

\section{Androgens}

B. fragilis reversibly reduces $17-$ keto group of A4 to a $17 \beta$-hydroxy derivative — $\mathrm{T}$ (Winter et al., 1984b), whereas a steroid-inducible $17 \alpha-\mathrm{HSD}$, capable of converting $\mathrm{T}$ to epitestosterone (epiT) was isolated from Eubacterium sp. VPI 12708 (de Prada et al., 1994). It is possible that intestinal microbiota are capable of epimerizing $\mathrm{T}$ to epiT, when both activities are present. EpiT is a hormone which regulates some androgen-dependent action and inhibits $5 \alpha$-reductase (Stárka, 2003). Pathways which contribute in T-epiT interconversion were not conclusively identified in human, so one cannot exclude significant role of microbiota in this process (Bellemare et al., 2005). These findings suggest possible role of microbiota in the regulation of $\mathrm{T}$ level and release of excessive androgens in humans (Donova et al., 2005).

Clostridium scindens belongs to the small number of intestinal bacterial species capable of bile acid $7 \alpha / \beta$ dehydroxylation, which leads to formation of secondary bile acids (Winter et al., 1984a). Furthermore, C. scindens possess steroid-17,20-desmolase which converts corticosteroids to androgens (Bokkenheuser et al., 1986; Krafft et al., 1987). In this process cortisol is transformed into 11- $\beta$-hydroxyandrostendione (11-OHA4), which is reabsorbed into the bloodstream and excreted in the urine (Ridlon et al., 2013). Since its discovery in 1953, 11-OHA4 has been a molecule of unknown biological significance. 11-OHA4 has insignificant androgen activity, nevertheless, in accordance with last studies, its derivatives are important metabolites in formation of novel androgens (Bloem et al., 2013). The main source of 11-OHA4 in humans is adrenal cortex, but intestine-derived 11-OHA4 may be also the important source of androgens precursors.

Studies conducted in nonobese diabetic (NOD) mouse model of type 1 diabetes (T1D) showed that in germ free (GF) environment gender bias in T1D had diminished (Markle et al., 2013). Relative to GF males, specific pathogen free (SPF) males had significantly higher levels of T. Interestingly, after transplantation of microbiome from SPF males to females, recipient $T$ levels had elevated and T1D morbidity had decreased. Similar results were observed in another study (Yurkovetskiy et al., 2013). These findings indicate a key role of microbiome in determining host $\mathrm{T}$ level and sex differences in susceptibility to autoimmune diseases. Lactobacillus renteri in drinking water prevents aging male mice from age-related testicular atrophy and elevates theirs $T$ level, probably acting on hypothalamic-pituitary level (Poutahidis et al., 2014). Authors of this study theorize that microbial impact on host $\mathrm{T}$ level may favor evolutionary success for the microbe and mammalian host. In general, GF compared to conventional mice have significantly lower weights of testis, epididymis, ductus deferens, kidneys, and adrenals (Fujiwara et al., 1990).

Gingival pathogens, Aggregatibacter actinomycetemcomitans, $P$. intermedius and Porphyromonas gingivalis are capable of reducing T to DHT and increase DHT synthesis by fibroblasts (Soory, 1995). Bacillus cereus and Streptococcus mutans also possess $5 \alpha$-steroid reductase activity and moreover, $3 \beta-, 17 \beta-$ and $20 \alpha-H S D$ s, which allows them to metabolize $\mathrm{T}$ and $\mathrm{P} 4$ within easy reach in the gingival tissues. During inflammatory periodontal disease, local elevated DHT level foster fibroblast metabolism and matrix production, thus has an impact on inflammatory repair. On the other hand, DHT influence bacterial metabolism, promoting gene expression which facilitates survival and dissemination of bacteria (Markou et al., 2009).

Thus, we propose a new term, analogous to estrobolome, the "androbolome". Detailed analysis of bacterial genes involved in androgens metabolism is necessary to understand a role of microbiome in androgen-dependent conditions like baldness, acne and prostate cancer.

\section{Progestins}

C. innocuum synthesize the $3 \alpha-5 \beta$-reductase and C. paraputrificum the $3 \beta-5 \beta$-reductase which are involved in in- 
activation of natural and synthethic progestins by reduction in the ring A (Bokkenheuser et al., 1983). Nevertheless, synthetic progestins, which are used as contraceptives, are much more resistant to reducing enzymes than natural analogs.

Reports on the impact of concomitant use of oral contraceptives and antibiotics on contraception effectiveness are contradictory (Weisberg, 1999; Dickinson et al., 2001; DeRossi \& Hersh, 2002; Toh et al., 2011). Rifampicin induces hepatic microsomal enzymes, thus facilitates oral contraceptive (OC) inactivation, whereas other commonly used antibiotics have neither pharmacokinetic nor pharmacodynamic interactions with OC. Probably rare cases of failure of OC associated with antibiotic use are caused by reduction of some microbial populations with $\beta$-glucuronidase activity and substantial loss of EHC of hormones.

As mentioned before, LPS reduces placental endocrine function. LPS administration to pregnant mice and ascending intrauterine infection in pregnant rabbits results in rapid P4 decrease and preterm parturition (Fidel et al., 1998).

\section{THYROID HORMONES}

The very first hypothesis concerning the role of intestinal bacteria in thyroid function appeared in early 1900s (Smith, 1982). Sir Arbuthnot Lane theorized that chronic constipation may lead to systemic dysfunction, including "exopthalmic goitre" (Graves disease) due to toxin absorption from intestine. Basing on this theory D. J. Harries concluded that intestinal bacteria unbalance leads to Graves disease due to an excessive absorption of tryptophan from the intestine, whereas parenchymatous goiter - from an excessive destruction of tryptophan (Harries, 1923). Current studies suggest that sir Lane was not completely wrong, because LPS actually influences thyroid function.

Nonthyroidal illness syndrome (NTIS, euthyroid sick syndrome) is a condition characterized by clinical euthyroidism with low triiodothyronine (T3), total thyroxine (T4), and normal or low thyroid stimulating hormone (TSH) concentration (McIver \& Gorman, 1997). NTIS is usually associated with serious disease (either infectious or non-infectious) or wasting. The Gram-negative bacterial LPS exposure may participate in pathogenesis of this condition in several ways. Endotoxin directly and by induced cytokines inhibits hepatic type I iodothyronine deiodinase (D1), that converts T4 to T3 (Yu \& Koenig, 2000) and induces the type II iodothyronine deiodinase (D2) in the mediobasal hypothalamus and anterior pituitary gland (Baur et al., 2000; Fekete et al., 2004). Induction of D2, that converts T4 to T3, in the central nervous system may cause suppression of TRH and TSH release. These effects are partly dependent on competition for limiting amounts of coactivators caused by the surplus of cytokines. IL-1, IL- $6, \mathrm{TNF} \alpha$ signaling pathways include NF- $x \mathrm{~B}$ and $\mathrm{AP}-1$, which interact with SRC-1 thus decreasing its availability for other pathways. SRC-1 in healthy individual increases the expression of hepatic D1 gene and its deficit decreases D1 activity (Yu \& Koenig, 2000; Boelen et al., 2004). It is worth pointing out that thyroid changes observed after combined administration of IL- $1 \alpha$, TNF $\alpha$, IL- 6 and IFN $\gamma$ are smaller than after administration of LPS (Boelen et al., 1995). Another mechanism responsible for NTIS during infection is LPS influence on thyroid hormone receptor (TR) in the liver. LPS decreases RXR and TR expression in hepatic extracts, reducing RXR/TR DNA binding (Beigneux et al., 2003).

$\mathrm{Na}^{+} / \mathrm{I}^{-}$symporter (NIS) plays a crucial role in thyroid physiology by participating in iodide uptake which is the main rate-limiting step in thyroid hormonogenesis. TSH induces NIS expression and stimulates its transport to basolateral membrane of thyrocytes. In turn, iodide inhibits NIS expression and increases NIS protein turnover, which contributes to the reduction of thyroid hormones' levels after treatment with large amounts of iodine (Wolff-Chaikoff effect) (Bizhanova \& Kopp, 2009). Studies conducted on Fisher rat thyroid cell line FRTL-5 revealed that LPS binding to TLR-4 on thyroid cells activates $\mathrm{NF}-x \mathrm{~B}$ pathway, which leads to the $\mathrm{p} 65$ subunit of NF- $x \mathrm{~B}$ interaction with a specific $x \mathrm{~B}$ site at the NIS enhancer (Nicola et al., 2010). Consequently, TSH-induced NIS expression and iodide uptake are stimulated (Nicola et al., 2009). Thyroglobulin (TG) gene expression is also enhanced by LPS, which acts with the involvement of Pax8 and TTF-1(Vélez et al., 2006). Apart from transcriptional level, LPS modifies TG expression also at posttranscriptional and posttranslational levels.

The exact role of these changes in thyroid hormone metabolism is unclear. Some authors postulate that NTIS should be treated with levothyroxine, despite clinical euthyroidism (Warner \& Beckett, 2010). On the other hand, low T3 concentration may be associated with lower energy expenditure and be beneficial in serious infection. Then, reaction of thyroid gland to bacterial LPS could be an adaptive change and proper physiological reaction to bacterial invasion.

Gut condition is strongly associated with thyroid function (Ebert, 2010). Hypothyroidism may lead to heartburn, dysphagia, vomiting, dyspepsia, intestine motility disorder and constipation. In turn, hyperthyroidism may be associated with diarrhea. Thyroid hormones' influence on gut condition is dependent on their direct action in enterocytes. T3 induces intestinal alkaline phosphatase (IAP) and represses lactase gene transcription in these cells, thus regulates their differentiation and function (Meng, 2001). SCFAs produced by the resident microbiota in the intestine lumen may accompany $\mathrm{T} 3$ in these processes. SCFAs (butyrate, propionate, acetate) are used by enterocytes as an energy source and are involved in regulation of host appetite and glucose level. They are mainly produced by Clostridium sp., which belong to the Gram-positive phylum of bacteria, Firmicutes. Most of their effects is exerted via free fatty acid receptors (FFAR) 2 and 3 (former G-protein coupled receptors (GPR) 43 and 41), locally in colon (Lin et al., 2012). They stimulate release of incretins, GLP-1 and PYY by intestinal cells L (Tolhurst et al., 2012). Nevertheless SCFAs are absorbed into bloodstream and SCFAs sensing receptors are expressed also in immune cells, adipose tissue and peripheral nervous system (Georgiadi \& Kersten, 2012). Main effects of SCFAs on endocrine system seem to be related to energy homeostasis - insulin sensitivity increases after SCFAs treatment, while in adipose tissue the SCFAs improve leptin secretion. These molecules are considered beneficial, improving colon function and carbohydrate metabolism. However, studies performed in vitro suggest that SCFAs may modulate hormonal system function in various locations, such as anterior pituitary gland, where they suppress GH secretion (Ishiwata et al., 2000, 2005) and enhance T3-induced stimulation of prolactin expression (Stanley \& Samuels, 1984).

SCFAs inhibit histone deacetylase HDAC-1 activity and activate the Mitogen-Activated Protein Kinase (MAPK) signaling pathway, which leads to hyperacetyl- 
ation of some histones and hyperphosphorylation of nuclear receptors (NR) coactivators, which in turn increases transcription of various NR, such as TR (Meng et al., 1999; Jansen et al., 2004). This leads to the enhancement of TR $\beta-1$ function and increases the T3-dependent IAP induction. IAP is a marker of crypt-villus differentiation, so we can conclude that bacterial SCFAs and host T3 cooperate in maintaining the proper intestinal epithelial development and homeostasis (Malo et al., 2013).

Varian et al. showed that $L$. reuteri supplementation improve function of thyroid gland in mice. L. reuteri consuming mice had higher fT4 levels, higher mass of thyroid gland tissue and increased height of the thyroid glandular epithelia as compared with their untreated counterpart (Varian et al., 2014). Mice treated with L. reuteri were also slimmer, more active and had healthier skin than control mice, which correlated with fT4 levels. These bacteria induce interleukin-10 production in the intestine, which stimulates host immune tolerance, triggered by anti-inflammatory CD25+ regulatory $\mathrm{T}$ cells. In CD25+-depleted mice, $L$. renteri supplementation was not beneficial for the thyroid function. Positive effects of bacteria on the thyroid function were also observed in other animals. For instance, female GF rats have smaller thyroids than CV (Vought et al., 1972). Moreover, lactic acid bacteria supplementation in the broiler chicken diets increased the blood plasma thyroid hormone level (Sohail et al., 2010; Chotinski \& Mihaylov, 2013). It is suggested that positive impact of probiotics on testicles, thyroid and probably ovaries in animals, inducing changes in GI microbiome composition may affect both the endocrine and immunological systems, thus influencing aging course (Varian et al., 2014).

Sulfation of T4 and T3 in the liver significantly facilitates deiodination by D1 to inactive derivatives rT3 and T2 (Wu et al., 2005). Under some conditions like prophylthiouracyl treatment, fetal development, selenium deficiency, or NTIS when D1 activity is low, sulfoconjugates may be hydrolyzed to bioactive T4 and T3 due to expression of sulfatases in different tissues and by intestinal bacteria (Kester et al., 2002). However, the significance of gut microflora in maintaining T3 level under conditions of reduced D1 activity is disputed (Veronikis et al., 1996). Physiologically about $20 \%$ of serum T3 is of intestine origin and T3-sulfate (T3S) is a reservoir, which can be recovered by sulfatases. Similarly, major billiary-excreted T3 metabolite — T3 glucuronide — may be hydrolyzed by microflora, which enables EHC of thyroid hormones (de Herder et al., 1989; Rutgers et al., 1989). Gut may be an important site in production of bioactive thyroid hormones and intestinal dysbiosis may lead to reduced T3S to T3 conversion and to T3 enterohepatic cycle dysfunction. One study suggests that intestinal bacteria are even capable of deiodination of thyroid hormones (DiStefano et al., 1993). However, this finding remains unconfirmed.

$7 \alpha$-dehydroxylation of primary bile acids by intestinal microbiota results in formation of secondary bile acids: lithocholic and deoxycholic. Main $7 \alpha$-dehydroxylating species isolated from human feces include Clostridium and Eubacterium (Wells \& Hylemon, 2000). Taurine-conjugated secondary bile acids, taurolithocholic acid and taurodeoxycholic acid are the most potent TGR5 ligands. In response to these compounds, the G-protein-coupled receptor TGR5 activates and subsequently intracellular cAMP level raises. Afterward, in brown adipocytes and human skeletal myocytes induction of the cAMP-dependent D2 occurs, which promotes energy expenditure (Watanabe et al., 2006). Paradoxically, some studies show that GF rats have significantly higher T3 to T4 ratio in the blood plasma than conventional animals (Ukai \& Mitsuma, 1978). It is possible that greater reabsorption of bile acids in these animals may lead to enhanced T3 producing enzymes expression (Wostmann, 1973).

\section{GROWTH HORMONE}

$\mathrm{GH}$ is secreted by anterior pituitary gland in a pulsatile manner dependent on the action of $\mathrm{GH}$ releasing hormone $(\mathrm{GHRH})$ and ghrelin, which stimulates $\mathrm{GH}$ secretion, and somatostatin which inhibits GH secretion (Vijayakumar et al., 2010). The physiological effects of $\mathrm{GH}$ results from direct by interacting with a specific receptor on the surface of cells and stimulation of insulin growth factor 1 and 2 (IGF-1 and -2) secretion by liver.

Lactobacillus plantarum may promote Drosophila systemic growth by affecting the TOR-dependent host nutrient sensing system controlling hormonal growth signaling (Storelli et al., 2011). Similarly, L. rhamnosus administration to zebrafish cause elevation of IGF-I, IGF-II, thus accelerates backbone calcification (Avella et al., 2012). It has been hypothesized that intestinal microbiota may also influence growth of mammals. For instance, in rabbits fed with probiotics, GH level elevates (Ghoneim \& Moselhy, 2013), whereas human infants fed with formula enriched with $L$. rhamnosus GG grew better compared to their control counterpart (Vendt et al., 2006).

LPS is a known exogenous factor which affects $\mathrm{GH}$ secretion and action (Figure 2). Studies performed on rats and domestic fowls revealed that LPS causes GH release inhibition (Curtis et al., 1980; Kasting \& Martin, 1982), whereas in human and sheep transitionally enhances GH secretion, probably acting on pituitary level (Lang et al., 1997; Briard et al., 1998; Daniel et al., 2002). Despite sustained increase in GH concentration, LPS injection results in a state of resistance to GH. LPS increases the production of proinflammatory cytokines like TNF- $\alpha$, interleukin-1 $\beta$ (IL-1b), and interleukin-6 (IL-6). $\mathrm{TNF}-\alpha$ suppresses $\mathrm{GH}$ receptor (GHR) expression by reduction of transactivators $\mathrm{Sp} 1 / \mathrm{Sp} 3$ binding to a GHR promotor (Denson et al., 2001), IL-6 up-regulates strong inhibitor of $\mathrm{GH}$ intracellular signal transduction, SOCS-3 (Wang et al., 2002a; Denson et al., 2003). Other mechanisms of LPS-dependent GH resistance are: decrease in IGF-1 concentration caused by liver cyclooxyganase-2 activation (Briard et al., 2000; Wang et al., 2002b; Martín et al., 2008), direct suppression of GHR expression by MyD88-dependent and -independent TLR4 signaling pathways (Dejkhamron et al., 2007) and promotion of proteolytic GHR cleavage (Wang et al., 2008). Moreover, the ability of $\mathrm{GH}$ to promote phosphorylation of signal transducer and activator of transcription (STAT) in the liver is reduced during sepsis (Hong-Brown et al., 2003). Furthermore, LPS administration alters IGFBP serum concentrations. In normal condition, IGFBP-3 forms a stable ternary complex with IGF and the acid labile subunit (ALS), so that IGF half-life is extended, IGFBP-1 serves as an inhibitor of IGF bioactivity, whereas IGFBP-2 is an optional IGF carrier in condition of low IGFBP-3 level (Donaghy \& Baxter, 1996). LPS administration promotes increased IGFBP-3 proteolysis in serum and/or its decreased synthesis in the liver (Priego et al., 2003), while IGFBP-1 accumulates in certain tissues, like skeletal muscles and blocks IGF-dependent protein synthesis (Frost \& Lang, 2004).

These studies may be crucial to understanding the mechanism of growth failure in children with inflamma- 


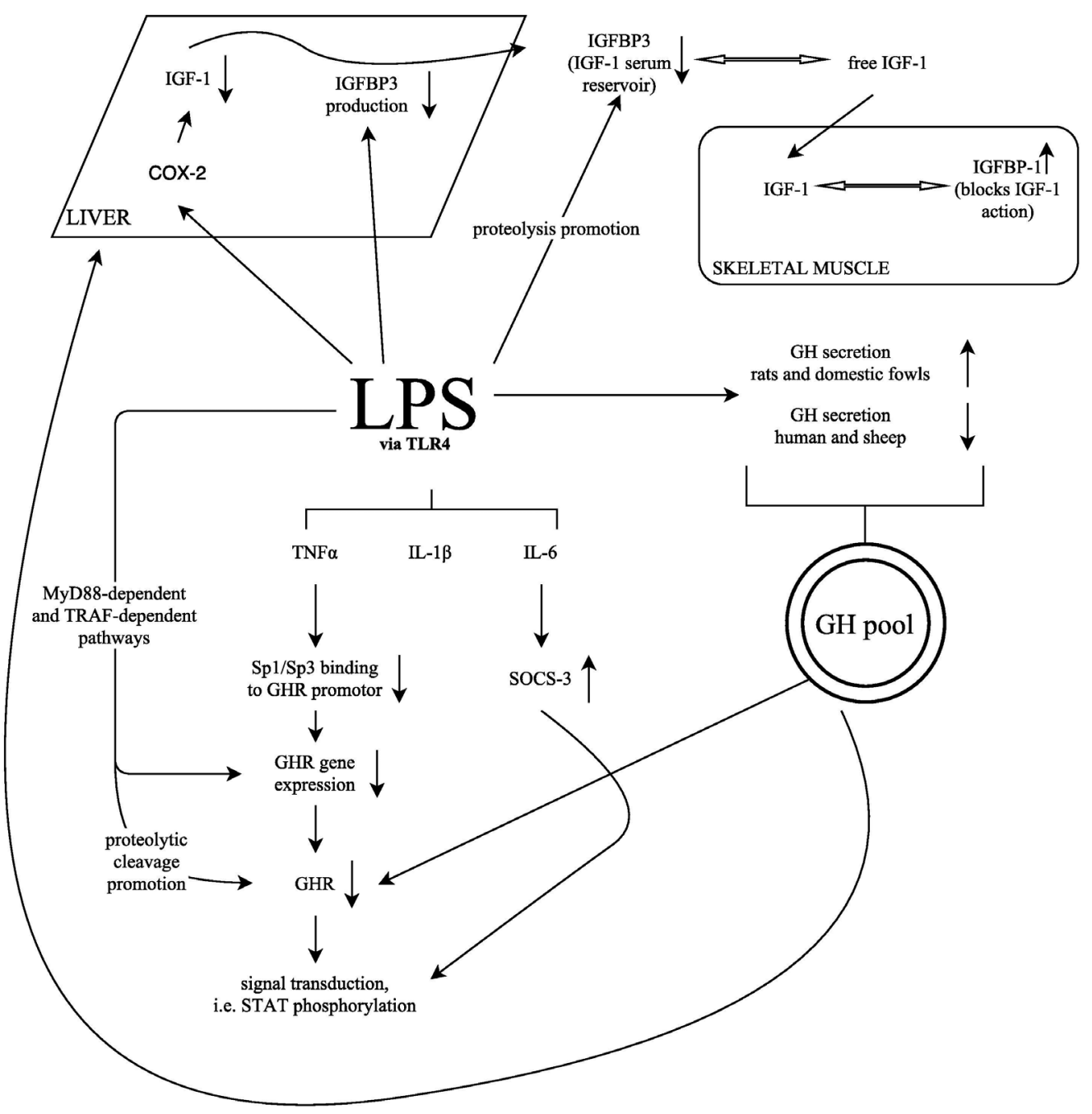

Figure 2. LPS influence on GH action.

Details, see main text. COX-2, cyclooxygenase-2; IGF-1, insulin like growth factor 1; IGFBP3, IGF binding protein 3; GH, growth hormone; GHR, GH receptor; LPS, lipopolysaccharide

tory bowel diseases (IBD). Due to increased intestinal permeability, systemic endotoxemia is a common finding in these patients and may underpin extra-intestinal complications. Chronic elevation of LPS binding protein (LBP) serum level has been proposed as a potentially useful marker of high refractory growth failure risk in pediatric IBD (Pasternak et al., 2010). During chronic infection or after sepsis, GH resistance develops in peripheral tissues, that may result for instance in muscle mass loss. Thus, LPS-dependent pathways leading to GH resistance may become the future therapy targets.

Another mechanism of bacteria-associated growth failure in children is observed in Helicobacter pylori carriers. An assessment of the anti-H. pylori antibodies in $\mathrm{GH}$ deficient short stature group, an idiopathic short stature group and control group, revealed that in children with idiopathic short stature the antibody positivity rate was significantly higher than in other groups (Takahashi et al., 2002). Possible explanation of this effect is decreased ghrelin production by enteroendocrine cells in the gastric mucosa. Ghrelin is a $\mathrm{GH}$ releasing peptide as a GH secretagogue type $1 \mathrm{~A}$ receptor (GHSR) ligand and has an important role in maintaining energy homeostasis and regulation of hunger. Chronic damage of gastric ghrelin-positive cells during $H$. pylori infection leads to decreased GH secretion, impaired hunger signals and in consequence growth retardation. Importantly, body composition improves in children after therapy (Osawa et al., 2006). Surprisingly, in some patients after H. pylori eradication, plasma ghrelin concentrations decrease and BMI increases (Pacifico et al., 2008). These variances may be dependent on the strain of bacteria: type I (producing the cag) is associated with lower ghrelin concentration than type II (without virulence factors), so eradication of different strains may lead to different effects (Deng et al., 2012).

Maternal oral Campylobacter rectus or $P$. gingivalis infection may cause intrauterine growth restriction (IUGR). These bacteria may invade placental tissues and promote hypermethylation in the promoter region-P0 of the Igf2 gene (Bobetsis et al., 2007). TLR-4 knockout mice do not develop IUGR phenotypes after systemic C. rectus infection, which emphasizes the crucial role of this receptor in placental immunity (Arce et al., 2012).

\section{PARATHYROID HORMONE AND GUT-KIDNEY AXIS}

Due to the deterioration of renal clearance during chronic kidney disease (CKD), many compounds accumulate and contribute to the uremic syndrome. These 
molecules, called uremic toxins are classified as: small water-soluble compounds (urea, guanidines, oxalate, phosphorus, polyamines), protein-bound compounds ( $\mathrm{p}$ cresol and p-cresylsulfate, indoles, homocysteine, furanpropionic acid) and middle molecules ( $\beta 2$-microglobulin, PTH) (Duranton et al., 2012). The originator of some uremic toxin is colon microbiome, which changes its composition during CKD. Low dietary fiber intake and impaired protein assimilation in the small intestine decreases carbohydrate to protein ratio in colon, thus promoting proteolytic bacterial species over saccharolytic ones. SCFA production by Lactobacillaceae and Prevotellaceae families decreases, whereas Bacteroides family overgrows and generates toxic solutes (Poesen et al., 2013). Gut bacteria convert tryptophan to indole, which is hydroxylated and sulfonated to indoxyl sulfate (IS) in the liver, whereas p-cresyl sulfate (PCS) is the product of bacterial tyrosine degradation followed by sulfate conjugation. Bone mineralization deficiency in CKD is called renal osteodystrophy. Endocrine changes which cause this condition are secondary hyperparathyroidism (SHP) and low vitamin $\mathrm{D}$ activation rate in kidneys. SHP in CKD may be a result of phosphate retention, hypocalcemia, decreased production of or resistance to calcitriol, abnormal sensitivity to calcium, direct effects of phosphate and skeletal resistance to PTH (Fukagawa et al., 2002). The mechanism of the latter stimulus, skeletal resistance to PTH, is related to IS and PCS produced by anaerobic bacteria. IS is taken up by osteoblasts via organic anion transporter 3 (OAT3) and afterward increases intracellular free radical production. Furthermore, IS down-regulates PTHR gene and decreases PTH-induced cAMP production in osteoblasts, that might lead to skeletal resistance to PTH (Nii-Kono et al., 2007; Goto et al., 2010).

Uremic toxins produced by bacteria might have an impact on function of other hormones. For instance, PCS activates ERK1/2 in mice skeletal muscle, thus promoting insulin resistance (Koppe et al., 2013). Also, uremic patients usually have low total T3 level, which may be caused by inhibition of T4 hepatocyte transport and subsequent T4 deiodination by IS (Lim et al., 1993).

\section{CONCLUSIONS}

Bacterial influence on endocrine system is difficult to understand and investigate, however new metabolomics and bioinformatics research provide information about bidirectional cross-talk between host hormones and microbiome. This knowledge is necessary to comprehend hormonal changes during a bacterial infection, antibiotic or probiotic treatment and diet modifications. Rational modifications of intestinal flora may decrease some hormone-dependent diseases risk, like breast and prostate cancer.

\section{REFERENCES}

Adlercreutz H, Pulkkinen MO, Hämäläinen EK, Korpela JT (1984) Studies on the role of intestinal bacteria in metabolism of synthetic and natural steroid hormones. I Steroid Biochem 20: 217-229.

Agrawal V, Jaiswal MK, Jaiswal YK (2011) Lipopolysaccharide induces alterations in ovaries and serum level of progesterone and 17ß-estradiol in the mouse. Fertil Steril 95: 1471-1474. doi: 10.1016/j.fertnstert.2010.08.046.

Agrawal V, Jaiswal MK, Jaiswal YK (2012) Gonadal and nongonadal FSHR and LHR dysfunction during lipopolysaccharide induced failure of blastocyst implantation in mouse. J Assist Reprod Genet 29: 163-173. doi: 10.1007/s10815-011-9696-4.
Akaza H (2012) Prostate cancer chemoprevention by soy isoflavones: role of intestinal bacteria as the "second human genome". Cancer Sci 103: 969-975. doi: 10.1111/j.1349-7006.2012.02257.x.

Allen JA, Diemer T, Janus P, Hales KH, Hales DB (2004) Bacterial endotoxin lipopolysaccharide and reactive oxygen species inhibit Leydig cell steroidogenesis via perturbation of mitochondria. Endocrine 25: 265-275.

Antunes LCM, Arena ET, Menendez A, Han J, Ferreira RBR, Buckner MMC, Lolic P, Madilao LL, Bohlmann J, Borchers CH, Finlay BB (2011) Impact of salmonella infection on host hormone metabolism revealed by metabolomics. Infect Immun 79: 1759-1769. doi: 10.1128/IAI.01373-10.

Aoki K (1978) A study of endotoxemia in ulcerative colitis and Crohn's disease. I. Clinical study. Acta Med Okayama 32: 147-158.

Arce RM, Caron KM, Barros SP, Offenbacher S (2012) Toll-like receptor 4 mediates intrauterine growth restriction after systemic Campylobacter rectus infection in mice. Mol Oral Microbiol 27: 373-381. doi: 10.1111/j.2041-1014.2012.00651.x.

Atkinson C (2004) Equol-Producing Bacteria and Estrogen Metabolism. Available at: http://oai.dtic.mil/oai/oai?verb=getRecord\&metadataPrefix =html\&identifier=ADA430355.

Atkinson C, Frankenfeld CL, Lampe JW (2005) Gut bacterial metabolism of the soy isoflavone daidzein: exploring the relevance to human health. Exp Biol Med (Maywood) 230: 155-170.

Avella MA, Place A, Du S-J, Williams E, Silvi S, Zohar Y, Carnevali O (2012) Lactobacillus rhamnosus accelerates zebrafish backbone calcification and gonadal differentiation through effects on the GnRH and IGF systems. PLoS One 7: e45572. doi: 10.1371/journal. pone.0045572.

Axelson M, Sjövall J (1983) Formation of catechol estrogens by intestinal bacterial demethylation of 2-methoxyestrone. Biochim Biophys Acta 751: 162-165.

Azrad M, Vollmer RT, Madden J, Dewhirst M, Polascik TJ, Snyder DC, Ruffin MT, Moul JW, Brenner DE, Demark-Wahnefried W (2013) Flaxseed-derived enterolactone is inversely associated with tumor cell proliferation in men with localized prostate cancer. $J$ Med Food 16: 357-360. doi: 10.1089/jmf.2012.0159.

Bartkiene E, Juodeikiene G, Basinskiene L, Liukkonen K-H, Adlercreutz H, Kluge H (2011) Enterolignans enterolactone and enterodiol formation from their precursors by the action of intestinal microflora and their relationship with non-starch polysaccharides in various berries and vegetables. LWT - Food Sci Technol 44: 48-53.

Battaglia DF, Bowen JM, Krasa HB, Thrun LA, Viguié C, Karsch FJ (1997) Endotoxin inhibits the reproductive neuroendocrine axis while stimulating adrenal steroids: a simultaneous view from hypophyseal portal and peripheral blood. Endocrinology 138: 4273-4281.

Battaglia DF, Brown ME, Krasa HB, Thrun LA, Viguié C, Karsch FJ (1998) Systemic challenge with endotoxin stimulates corticotropin-releasing hormone and arginine vasopressin secretion into hypophyseal portal blood: coincidence with gonadotropin-releasing hormone suppression. Endocrinology 139: 4175-4181.

Baur A, Bauer K, Jarry H, Köhrle J (2000) Effects of proinflammatory cytokines on anterior pituitary 5 '-deiodinase type I and type II. J Endocrinol 167: 505-515.

Beigneux AP, Moser AH, Shigenaga JK, Grunfeld C, Feingold KR (2003) Sick euthyroid syndrome is associated with decreased TR expression and DNA binding in mouse liver. Am J Physiol Endocrinol Metab 284: E228-36.

Bellemare V, Faucher F, Breton R, Luu-The V (2005) Characterization of 17alpha-hydroxysteroid dehydrogenase activity (17alpha-HSD) and its involvement in the biosynthesis of epitestosterone. BMC Biochem 6: 12 .

Bizhanova A, Kopp P (2009) Minireview: The sodium-iodide symporter NIS and pendrin in iodide homeostasis of the thyroid. Endocrinology 150: 1084-1090. doi: 10.1210/en.2008-1437.

Bloem LM, Storbeck K-H, Schloms L, Swart AC (2013) $11 \beta$-hydroxyandrostenedione returns to the steroid arena: biosynthesis, metabolism and function. Molecules 18: 13228-13244. doi: 10.3390/molecules181113228.

Bobetsis YA, Barros SP, Lin DM, Weidman JR, Dolinoy DC, Jirtle RL, Boggess KA, Beck JD, Offenbacher S (2007) Bacterial infection promotes DNA hypermethylation. J Dent Res 86: 169-174.

Boelen A, Kwakkel J, Platvoet-ter Schiphorst M, Mentrup B, Baur A, Koehrle J, Wiersinga W (2004) Interleukin-18, a proinflammatory cytokine, contributes to the pathogenesis of non-thyroidal illness mainly via the central part of the hypothalamus-pituitary-thyroid axis. Eur J Endocrinol 151: 497-502.

Boelen A, Platvoet-ter Schiphorst MC, Bakker O, Wiersinga WM (1995) The role of cytokines in the lipopolysaccharide-induced sick euthyroid syndrome in mice. J Endocrinol 146: 475-483.

Bokkenheuser VD, Winter J, Cohen BI, O'Rourke S, Mosbach EH (1983) Inactivation of contraceptive steroid hormones by human intestinal clostridia. J Clin Microbiol 18: 500-504.

Bokkenheuser VD, Winter J, Morris GN, Locascio S (1986) Steroid desmolase synthesis by Eubacterium desmolans and Clostridium cadavaris. Appl Environ Microbiol 52: 1153-1156. 
Borisenkov MF, Bakutova LA, Latkin DS, Golovchenko V V, Vityazev F V (2011) Interaction of microbial $\beta$-glucuronidase with vegetable pectins. J Agric Food Chem 59: 9922-9926. doi: 10.1021/jf202307r.

Briard N, Dadoun F, Pommier G, Sauze N, Lebouc Y, Oliver C, Dutour A (2000) IGF-I/IGFBPs system response to endotoxin challenge in sheep. $J$ Endocrinol 164: 361-369.

Briard N, Guillaume V, Frachebois C, Rico-Gomez M, Sauze N, Oliver C, Dutour A (1998) Endotoxin injection increases growth hormone and somatostatin secretion in sheep. Endocrinology 139: 2662-2669.

Buck K, Zaineddin AK, Vrieling A, Heinz J, Linseisen J, Flesch-Janys D, Chang-Claude J (2011) Estimated enterolignans, lignan-rich foods, and fibre in relation to survival after postmenopausal breast cancer. Br J Cancer 105: 1151-1157. doi: 10.1080/01635581.2012.683227.

Burcelin R, Serino M, Chabo C, Blasco-Baque V, Amar J (2011) Gut microbiota and diabetes: from pathogenesis to therapeutic perspective. Acta Diabetol 48: 257-273. doi: 10.1007/s00592-011-0333-6.

Carnevali O, Avella MA, Gioacchini G (2013) Effects of probiotic administration on zebrafish development and reproduction. Gen Comp Endocrinol 188: 297-302. doi: 10.1016/j.ygcen.2013.02.022.

Carreau C, Flouriot G, Bennetau-Pelissero C, Potier M (2008) Enterodiol and enterolactone, two major diet-derived polyphenol metabolites have different impact on ERalpha transcriptional activation in human breast cancer cells. J Steroid Biochem Mol Biol 110: 176-185. doi: 10.1016/i.jsbmb.2008.03.032.

Cavalieri E, Chakravarti D, Guttenplan J, Hart E, Ingle J, Jankowiak R, Muti P, Rogan E, Russo J, Santen R, Sutter T (2006) Catechol estrogen quinones as initiators of breast and other human cancers: implications for biomarkers of susceptibility and cancer prevention. Biocbim Biophys Acta 1766: 63-78.

Chotinski D, Mihaylov R (2013) Effect of probiotics and avotan on the level of thyroid hormones in the blood plasma of broiler chickens. Bulg J Agric Sci 19: 817-821. Available at: http://agris.fao.org/ agris-search/search.do? recordID=BG20130433.

Clavel T, Henderson G, Alpert C-A, Philippe C, Rigottier-Gois L, Doré J, Blaut M (2005) Intestinal bacterial communities that produce active estrogen-like compounds enterodiol and enterolactone in humans. Appl Environ Microbiol 71: 6077-6085.

Curtis MJ, Flack IH, Harvey S (1980) The effect of Eschericbia coli endotoxins on the concentrations of corticosterone and growth hormone in the plasma of the domestic fowl. Res Vet Sci 28: 123-127.

Dadoun F, Guillaume V, Sauze N, Farisse J, Velut JG, Orsoni JC, Gaillard R, Oliver C (1998) Effect of endotoxin on the hypothalamic-pituitary-adrenal axis in sheep. Eur J Endocrinol 138: 193-197.

Daniel J, Whitlock B, Wagner C, Sartin J (2002) Regulation of the growth hormone and luteinizing hormone response to endotoxin in sheep. Domest Anim Endocrinol 23: 361-370.

Debas HT (1981) The colon as an endocrine organ. Dig Dis Sci 26: 193-194.

Decroos K, Eeckhaut E, Possemiers S, Verstraete W (2006) Administration of equol-producing bacteria alters the equol production status in the simulator of the gastrointestinal microbial ecosystem (SHIME) J Nutr 136: 946-952.

Dejkhamron P, Thimmarayappa J, Kotlyarevska K, Sun J, Lu C, Bonkowski EL, Denson LA, Menon RK (2007) Lipopolysaccharide (LPS) directly suppresses growth hormone receptor (GHR) expression through MyD88-dependent and -independent Toll-like receptor-4/MD2 complex signaling pathways. Mol Cell Endocrinol 274: 35-42.

Deng Z-H, Chu B, Xu Y-Z, Zhang B, Jiang L-R (2012) Influence of Helicobacter pylori infection on ghrelin levels in children. World J Gastroenterol 18: 5096-5100. doi: 10.3748/wig.v18.i36.5096.

Denson LA, Held MA, Menon RK, Frank SJ, Parlow AF, Arnold DL (2003) Interleukin-6 inhibits hepatic growth hormone signaling via upregulation of Cis and Socs-3. Am J Physiol Gastrointest Liver Physiol 284: G646-54.

Denson LA, Menon RK, Shaufl A, Bajwa HS, Williams CR, Karpen SJ (2001) TNF-alpha downregulates murine hepatic growth hormone receptor expression by inhibiting $\mathrm{Sp} 1$ and $\mathrm{Sp} 3$ binding. J Clin Invest 107: 1451-1458.

DeRossi SS, Hersh E V (2002) Antibiotics and oral contraceptives. Dent Clin North Am 46: 653-664.

Dickinson BD, Altman RD, Nielsen NH, Sterling ML (2001) Drug interactions between oral contraceptives and antibiotics. Obstet Gynecol 98: 853-860.

Dietert R, Dietert J (2012) The completed self: an immunological view of the human-microbiome superorganism and risk of chronic diseases. Entropy 14: 2036-2065.

DiStefano JJ, de Luze A, Nguyen TT (1993) Binding and degradation of 3,5,3'-triiodothyronine and thyroxine by rat intestinal bacteria. Am J Physiol 264: E966-72.

Donaghy AJ, Baxter RC (1996) Insulin-like growth factor bioactivity and its modification in growth hormone resistant states. Baillieres Clin Endocrinol Metab 10: 421-446.
Donova MV, Egorova OV, Nikolayeva VM (2005) Steroid $17 \beta$-reduction by microorganisms - a review. Process Biochem 40: 2253-2262.

Duranton F, Cohen G, De Smet R, Rodriguez M, Jankowski J, Vanholder R, Argiles A (2012) Normal and pathologic concentrations of uremic toxins. J Am Soc Nephrol 23: 1258-1270. doi: 10.1681/ ASN.2011121175.

Ebert EC (2010) The thyroid and the gut. J Clin Gastroenterol 44: 402406. doi: 10.1097/MCG.0b013e3181d6bc3e

Eeckhaut E, Struijs K, Possemiers S, Vincken J-P, Keukeleire D De, Verstraete W (2008) Metabolism of the lignan macromolecule into enterolignans in the gastrointestinal lumen as determined in the simulator of the human intestinal microbial ecosystem. J Agric Food Chem 56: 4806-4812. doi: 10.1021/jf800101s.

Eldere Van J, Robben J, De Pauw G, Merckx R, Eyssen H (1988) Isolation and identification of intestinal steroid-desulfating bacteria from rats and humans. Appl Environ Microbiol 54: 2112-2117.

Eliassen AH, Missmer SA, Tworoger SS, Hankinson SE (2008) Circulating 2-hydroxy- and 16alpha-hydroxy estrone levels and risk of breast cancer among postmenopausal women. Cancer Epidemiol Biomarkers Prev 17: 2029-2035. doi: 10.1158/1055-9965.

Erridge C, Attina T, Spickett CM, Webb DJ (2007) A high-fat meal induces low-grade endotoxemia: evidence of a novel mechanism of postprandial inflammation. Am J Clin Nutr 86: 1286-1292.

Fekete C, Gereben B, Doleschall M, Harney JW, Dora JM, Bianco AC, Sarkar S, Liposits Z, Rand W, Emerson C, Kacskovics I, Larsen PR, Lechan RM (2004) Lipopolysaccharide induces type 2 iodothyronine deiodinase in the mediobasal hypothalamus: implications for the nonthyroidal illness syndrome. Endocrinology 145: 1649-1655.

Fidel PI, Romero R, Maymon E, Hertelendy F (1998) Bacteria-induced or bacterial product-induced preterm parturition in mice and rabbits is preceded by a significant fall in serum progesterone concentrations. J Matern Fetal Med 7: 222-226.

Flores R, Shi J, Fuhrman B, Xu X, Veenstra TD, Gail MH, Gajer P, Ravel J, Goedert JJ (2012a) Fecal microbial determinants of fecal and systemic estrogens and estrogen metabolites: a cross-sectional study. J Transl Med 10: 253. doi: 10.1186/1479-5876-10-253.

Flores R, Shi J, Gail MH, Gajer P, Ravel J, Goedert JJ (2012b) Association of fecal microbial diversity and taxonomy with selected enzymatic functions. Highlander SK ed. PLoS One 7: e39745. doi: 10.1371/journal.pone.0039745.

Frost RA, Lang CH (2004) Alteration of somatotropic function by proinflammatory cytokines. J Anim Sci 82 (E-Suppl): E100-E109.

Fuglsang A, Rattray FP, Nilsson D, Nyborg NCB (2003) Lactic acid bacteria: inhibition of angiotensin converting enzyme in vitro and in vivo. Antonie Van Leeunvenboek 83: 27-34.

Fujisawa T, Mori M (1996) Influence of bile salts on $\beta$-glucuronidase activity of intestinal bacteria. Lett Appl Microbiol 22: 271-274.

Fujiwara M, Kumai M, Oowada T, Ozaki A, Mizutani T, Taya K, Sasamoto S, Mitsouka T (1990) Effect of intestinal microflora on male reproductive organs in BALB/c mice. BIFIDUS -Flores, Fructus et Semina 4: 13-20. Available at: https://www.jstage.jst.go.jp/article/ jim1987/4/1/4_1_13/_article

Fukagawa M, Kazama JJ, Kurokawa K (2002) Renal osteodystrophy and secondary hyperparathyroidism. Nephrol Dial Transplant 17 (Suppl 1): 2-5.

Gao Z, Yin J, Zhang J, Ward RE, Martin RJ, Lefevre M, Cefalu WT, Ye J (2009) Butyrate improves insulin sensitivity and increases energy expenditure in mice. Diabetes 58: 1509-1517. doi: 10.2337/db081637.

García-Gómez E, González-Pedrajo B, Camacho-Arroyo I (2013) Role of sex steroid hormones in bacterial-host interactions. Biomed Res Int 2013: 928290. doi: 10.1155/2013/928290.

Georgiadi A, Kersten S (2012) Mechanisms of gene regulation by fatty acids. Adv Nutr 3: 127-134. doi: 10.3945/an.111.001602.

Ghoneim MA, Moselhy SS (2013) Antioxidant status and hormonal profile reflected by experimental feeding of probiotics. Toxicol Ind Health; doi: $10.1177 / 0748233713506768$

Gloux K, Berteau O, El Oumami H, Béguet F, Leclerc M, Doré J (2011) A metagenomic $\beta$-glucuronidase uncovers a core adaptive function of the human intestinal microbiome. Proc Natl Acad Sci USA 108 (Suppl 1): 4539-4546. doi: 10.1073/pnas.1000066107.

Gobbetti M, Ferranti P, Smacchi E, Goffredi F, Addeo F (2000) Production of angiotensin-I-converting-enzyme-inhibitory peptides in fermented milks started by Lactobacillus delbrueckii subsp. bulgaricus SS1 and Lactococcus lactis subsp. cremoris FT4. Appl Environ Microbiol 66: 3898-3904.

Goldin B, Gorbach SL (1977) Alterations in fecal microflora enzymes related to diet, age, lactobacillus supplements, and dimethylhydrazine. Cancer 40: 2421-2426.

Goldin BR, Adlercreutz H, Gorbach SL, Warram JH, Dwyer JT, Swenson L, Woods MN (1982) Estrogen excretion patterns and plasma levels in vegetarian and omnivorous women. N Engl J Med 307: 1542-1547. 
Goldin BR, Gorbach SL (1984) The effect of milk and lactobacillus feeding on human intestinal bacterial enzyme activity. Am J Clin Nutr 39: 756-761.

Goldin BR, Swenson L, Dwyer J, Sexton M, Gorbach SL (1980) Effect of diet and Lactobacillus acidophilus supplements on human fecal bacterial enzymes. I Natl Cancer Inst 64: 255-261.

Gorbach SL (1984) Estrogens, breast cancer, and intestinal flora. Rev Infect Dis 6 (Suppl 1): S85-90.

Goto S, Fujii H, Hamada Y, Yoshiya K, Fukagawa M (2010) Association between indoxyl sulfate and skeletal resistance in hemodialysis patients. Ther Apher Dial 14: 417-423. doi: 10.1111/j.1744-9987.2010.00813.x.

Gozgit JM, Nestor KM, Fasco MJ, Pentecost BT, Arcaro KF (2004) Differential action of polycyclic aromatic hydrocarbons on endogenous estrogen-responsive genes and on a transfected estrogen-responsive reporter in MCF-7 cells. Toxicol Appl Pharmacol 196: 58-67.

Gudiel-Urbano M, Goñi I (2002) Effect of short-chain fructooligosaccharides and cellulose on cecal enzyme activities in rats. Ann Nutr Metab 46: 254-258.

Guidet B, Barakett V, Vassal T, Petit JC, Offenstadt G (1994) Endotoxemia and bacteremia in patients with sepsis syndrome in the intensive care unit. Chest 106: 1194-1201.

Hall D (2001) Nutritional Influences on Estrogen Metabolism. Appl Nutr Sci Reports 1: 1-8.

Hämäläinen E, Korpela JT, Adlercreutz H (1987) Effect of oxytetracycline administration on intestinal metabolism of oestrogens and on plasma sex hormones in healthy men. Gut 28: 439-445.

Han S-Y, Huh C-S, Ahn Y-T, Lim K-S, Baek Y-J, Kim D-H (2005) Hepatoprotective effect of lactic acid bacteria, inhibitors of beta-glucuronidase production against intestinal microflora. Arch Pharm Res 28: 325-329.

Harries DJ (1923) The influence of intestinal bacteria upon the the thyroid gland. $\mathrm{Br}$ Med J 1: 553-555.

Hasday JD, Bascom R, Costa JJ, Fitzgerald T, Dubin W (1999) Bacterial endotoxin is an active component of cigarette smoke. Chest 115: 829-835.

Hedger MP (2011) Toll-like receptors and signalling in spermatogenesis and testicular responses to inflammation--a perspective. I Reprod Immunol 88: 130-141. doi: 10.1016/j.jri.2011.01.010.

Herath S, Williams EJ, Lilly ST, Gilbert RO, Dobson H, Bryant CE, Sheldon IM (2007) Ovarian follicular cells have innate immune capabilities that modulate their endocrine function. Reproduction 134: 683-693.

De Herder WW, Hazenberg MP, Pennock-Schröder AM, Oosterlaken AC, Rutgers M, Visser TJ (1989) On the enterohepatic cycle of triiodothyronine in rats; importance of the intestinal microflora. Life Sci 45: 849-856.

Holzer P, Reichmann F, Farzi A (2012) Neuropeptide Y, peptide YY and pancreatic polypeptide in the gut-brain axis. Neuropeptides 46: 261-274. doi: 10.1016/j.npep.2012.08.005.

Hong-Brown LQ, Brown CR, Cooney RN, Frost RA, Lang CH (2003) Sepsis-induced muscle growth hormone resistance occurs independently of STAT5 phosphorylation. Am J Physiol Endocrinol Metab 285: E63-72.

Huang CT, Woodward WE, Hornick RB, Rodriguez JT, Nichols BL (1976) Fecal steroids in diarrhea. I. Acute shigellosis. Am J Clin Nutr 29: 949-955.

Hughes DT, Sperandio V (2008) Inter-kingdom signalling: communication between bacteria and their hosts. Nat Rev Microbiol 6: 111-120. doi: $10.1038 /$ nrmicro1836.

Iarŭmov N, Evtimov R, Argirov D (2004) [The role of bacterial translocation and endotoxemia in pathogenesis of obturation ileus, caused by colorectal carcinoma. Limulus test - a method for quick diagnostics of endotoxemia]. Khirurgiza 60: 48-55.

Ishiwata H, Katoh K, Chen C, Yonezawa T, Sasaki Y, Obara Y (2005) Suppressing actions of butyrate on growth hormone $(\mathrm{GH})$ secretion induced by $\mathrm{GH}$-releasing hormone in rat anterior pituitary cells. Gen Comp Endocrinol 143: 222-230.

Ishiwata H, Nagano M, Sasaki Y, Chen C, Katoh K (2000) Short-chain fatty acids inhibit the release and content of growth hormone in anterior pituitary cells of the goat. Gen Comp Endocrinol 118: 400-406.

Ishiwata N, Melby MK, Mizuno S, Watanabe S (2009) New equol supplement for relieving menopausal symptoms: randomized, placebo-controlled trial of Japanese women. Menopause 16: 141-148. doi: 10.1097/gme.0b013e31818379fa.

Jacob SP, Nath S, Zade RM (2012) Effect of periodontal therapy on circulating levels of endotoxin in women with periodontitis: a pilot clinical trial. Indian J Dent Res 23: 714-718. doi: 10.4103/09709290.111244.

Jansen MS, Nagel SC, Miranda PJ, Lobenhofer EK, Afshari CA, McDonnell DP (2004) Short-chain fatty acids enhance nuclear receptor activity through mitogen-activated protein kinase activation and histone deacetylase inhibition. Proc Natl Acad Sci USA 101: 7199-7204.

Järvenpää P, Kosunen T, Fotsis T, Adlercreutz H (1980) In vitro metabolism of estrogens by isolated intestinal micro-organisms and by human faecal microflora. J Steroid Biochem 13: 345-349.
Jobe SO, Tyler CT, Magness RR (2013) Aberrant synthesis, metabolism, and plasma accumulation of circulating estrogens and estrogen metabolites in preeclampsia implications for vascular dysfunction. Hypertension 61: 480-487. doi: 10.1161/HYPERTENSIONAHA.111.201624.

Kasting NW, Martin JB (1982) Altered release of growth hormone and thyrotropin induced by endotoxin in the rat. Am J Physiol Endocrinol Metab 243: E332-337.

Kester MHA, Kaptein E, Van Dijk CH, Roest TJ, Tibboel D, Coughtrie MWH, Visser TJ (2002) Characterization of iodothyronine sulfatase activities in human and rat liver and placenta. Endocrinology 143: 814-819.

Kim DH, Jin YH, Park JB, Kobashi K (1994) Silymarin and its components are inhibitors of beta-glucuronidase. Biol Pharm Bull 17: 443-445.

Kisiela M, Skarka A, Ebert B, Maser E (2012) Hydroxysteroid dehydrogenases (HSDs) in bacteria: a bioinformatic perspective. I Steroid Biochem Mol Biol 129: 31-46. doi: 10.1016/j.jsbmb.2011.08.002.

Koppe L, Pillon NJ, Vella RE, Croze ML, Pelletier CC, Chambert S, Massy Z, Glorieux G, Vanholder R, Dugenet Y, Soula HA, Fouque D, Soulage CO (2013) p-Cresyl sulfate promotes insulin resistance associated with CKD. J Am Soc Nephrol 24: 88-99. doi: 10.1681/ ASN.2012050503.

Kornman KS, Loesche WJ (1982) Effects of estradiol and progesterone on Bacteroides melaninogenicus and Bacteroides gingivalis. Infect Immun 35: $256-263$

Krafft AE, Winter J, Bokkenheuser VD, Hylemon PB (1987) Cofactor requirements of steroid-17-20-desmolase and 20 $\alpha$-hydroxysteroid dehydrogenase activities in cell extracts of Clostridium scindens. I Steroid Biochem 28: 49-54.

Kuijsten A, Arts ICW, Hollman PCH, van't Veer P, Kampman E (2006) Plasma enterolignans are associated with lower colorectal adenoma risk. Cancer Epidemiol Biomarkers Prev 15: 1132-1136.

Lang CH, Pollard V, Fan J, Traber LD, Traber DL, Frost RA, Gelato MC, Prough DS (1997) Acute alterations in growth hormone-insulin-like growth factor axis in humans injected with endotoxin. Am J Physiol 273: R371-8.

Latman NS, Kishore V, Bruot BC (1994) 16-Epiestriol: An anti-inflammatory steroid without glycogenic activity. J Pharm Sci 83: 874-877.

Lim CF, Bernard BF, de Jong M, Docter R, Krenning EP, Hennemann $G$ (1993) A furan fatty acid and indoxyl sulfate are the putative inhibitors of thyroxine hepatocyte transport in uremia. I Clin Endocrinol Metab 76: 318-324.

Lin H V, Frassetto A, Kowalik EJ, Nawrocki AR, Lu MM, Kosinski JR, Hubert JA, Szeto D, Yao X, Forrest G, Marsh DJ (2012) Butyrate and propionate protect against diet-induced obesity and regulate gut hormones via free fatty acid receptor 3-independent mechanisms. ed. Brennan L. PLoS One 7: e35240. doi: 10.1371/journal. pone. 0035240

Lu Y-C, Yeh W-C, Ohashi PS (2008) LPS/TLR4 signal transduction pathway. Cytokine 42: 145-151. doi: 10.1016/j.cyto.2008.01.006.

Lund TD, Munson DJ, Haldy ME, Setchell KDR, Lephart ED, Handa RJ (2004) Equol is a novel anti-androgen that inhibits prostate growth and hormone feedback. Biol Reprod 70: 1188-1195.

Macdonald IA, Bokkenheuser VD, Winter J, McLernon AM, Mosbach EH (1983) Degradation of steroids in the human gut. I Lipid Res 24: 675-700.

Maes M, Kubera M, Leunis J-C (2008) The gut-brain barrier in major depression: intestinal mucosal dysfunction with an increased translocation of LPS from gram negative enterobacteria (leaky gut) plays a role in the inflammatory pathophysiology of depression. Neuro Endocrinol Lett 29: 117-124.

Magata F, Horiuchi M, Mivamoto A, Shimizu T (2014b) Peptidoglycan inhibits progesterone and androstenedione production in bovine ovarian theca cells. Toxicol In Vitro 28: 961-967. doi: 10.1016/j. tiv.2014.04.005.

Magata F, Horiuchi M, Miyamoto A, Shimizu T (2014a) Lipopolysaccharide (LPS) Inhibits steroid production in theca cells of bovine follicles in vitro: distinct effect of LPS on theca cell function in preand post-selection follicles. I Reprod Dev 60: 280-287.

Malo MS, Zhang W, Alkhoury F, Pushpakaran P, Abedrapo MA, Mozumder M, Fleming E, Siddique A, Henderson JW, Hodin RA (2013) Thyroid hormone positively regulates the enterocyte differentiation marker intestinal alkaline phosphatase gene via an atypical response element. Mol Endocrinol. Available at: http://press.endocrine.org/doi/abs/10.1210/me.2003-0351?url_ver=Z39.88-2003\&rfr id=ori:rid:crossref.org\&rfr dat $=$ cr pub $=$ pubmed.

Markle JGM, Frank DN, Mortin-Toth S, Robertson CE, Feazel LM, Rolle-Kampczyk U, von Bergen M, McCoy KD, Macpherson AJ, Danska JS (2013) Sex differences in the gut microbiome drive hormone-dependent regulation of autoimmunity. Science 339: 1084 1088. doi: $10.1126 /$ science. 1233521.

Markou E, Eleana B, Lazaros T, Antonios K (2009) The influence of sex steroid hormones on gingiva of women. Open Dent J 3: 114 119. doi: 10.2174/1874210600903010114. 
Marshall JC (2005) Lipopolysaccharide: an endotoxin or an exogenous hormone? Clin Infect Dis 41 Suppl. 7, S470-80.

Martín AI, López-Menduiña M, Castillero E, Granado M, Villanúa MA, López-Calderón A (2008) Cyclooxygenase-2 [corrected] activation by endotoxin mediates the decrease in IGF1, but not in IGFBP3, [corrected] gene expression in the liver. J Endocrinol 198: 385-394. doi: 10.1677/JOE-08-0205.

Matsuoka Y, Furuyashiki T, Bito H, Ushikubi F, Tanaka Y, Kobayashi T, Muro S, Satoh N, Kayahara T, Higashi M, Mizoguchi A, Shichi H, Fukuda Y, Nakao K, Narumiya S (2003) Impaired adrenocorticotropic hormone response to bacterial endotoxin in mice deficient in prostaglandin E receptor EP1 and EP3 subtypes. Proc Natl Acad Sci U S A 100: 4132-4137.

McIver B, Gorman CA (1997) Euthyroid sick syndrome: an overview. Thyroid 7: 125-132.

Meng S (2001) Thyroid hormone and the D-type cyclins interact in regulating enterocyte gene transcription. J Gastrointest Surg 5: 49-55.

Meng S, Wu JT, Archer SY, Hodin RA (1999) Short-chain fatty acids and thyroid hormone interact in regulating enterocyte gene transcription. Surgery 126: 293-298.

Minami M, Oowada T, Mizutani T, Saito K, Adachi J, Fujisawa T, Mitsuoka T (1987) Estrous Cycle and Vaginal Flora in Conventionalized and Gnotobiotic BALB/c Mice. BIFIDUS - Flores, Fructus et Semina 1: 25-32. Available at: https://www.jstage.jst.go.jp/article/ jim1987/1/1/1_1_25/_article.

De Moreno de LeBlanc A, Perdigón G (2005) Reduction of beta-glucuronidase and nitroreductase activity by yoghurt in a murine colon cancer model. Biocell 29: 15-24.

Mroczyńska M, Libudzisz Z (2010) Beta-glucuronidase and beta-glucosidase activity of Lactobacillus and Enterococcus isolated from human feces. Pol J Microbiol 59: 265-269.

Nahum A, Hoyt J, Schmitz L, Moody J, Shapiro R, Marini JJ (1997) Effect of mechanical ventilation strategy on dissemination of intratracheally instilled Escherichia coli in dogs. Crit Care Med 25: 17331743.

Nicola JP, Nazar M, Mascanfroni ID, Pellizas CG, Masini-Repiso AM (2010) NF-kappaB p65 subunit mediates lipopolysaccharide-induced $\mathrm{Na}(+) / \mathrm{I}(-)$ symporter gene expression by involving functional interaction with the paired domain transcription factor Pax8. Mol Endocrinol 24: 1846-1862. doi: 10.1210/me.2010-0102.

Nicola JP, Vélez ML, Lucero AM, Fozzatti L, Pellizas CG, Masini-Repiso AM (2009) Functional toll-like receptor 4 conferring lipopolysaccharide responsiveness is expressed in thyroid cells. Endocrinology 150: 500-508. doi: 10.1210/en.2008-0345.

Nii-Kono T, Iwasaki Y, Uchida M, Fujieda A, Hosokawa A, Motojima M, Yamato H, Kurokawa K, Fukagawa M (2007) Indoxyl sulfate induces skeletal resistance to parathyroid hormone in cultured osteoblastic cells. Kidney Int 71: 738-743.

Norris V, Molina F, Gewirtz AT (2013) Hypothesis: bacteria control host appetites. J Bacteriol 195: 411-416. doi: 10.1128/JB.01384-12.

Okada T, Matsuzaki N, Sawai K, Nobunaga T, Shimoya K, Suzuki K, Taniguchi N, Saji F, Murata Y (1997) Chorioamnionitis reduces placental endocrine functions: the role of bacterial lipopolysaccharide and superoxide anion. J Endocrinol 155: 401-410.

Osawa H, Kita H, Ohnishi H, Nakazato M, Date Y, Bowlus CL, Ishino $\mathrm{Y}$, Watanabe E, Shiiya T, Ueno H, Hoshino $\mathrm{H}$, Satoh K, Sugano K (2006) Changes in plasma ghrelin levels, gastric ghrelin production, and body weight after Helicobacter pylori cure. $J$ Gastroenterol 41: 954-961.

Pacifico L, Anania C, Osborn JF, Ferrara E, Schiavo E, Bonamico M, Chiesa C (2008) Long-term effects of Helicobacter pylori eradication on circulating ghrelin and leptin concentrations and body composition in prepubertal children. Eur J Endocrinol 158: 323-332. doi: 10.1530/EJE-07-0438.

Pålsson-McDermott EM, O’Neill LA (2004) Signal transduction by the lipopolysaccharide receptor, Toll-like receptor-4. Immunology 113: 153-162.

Pasternak BA, D’Mello S, Jurickova II, Han X, Willson T, Flick L, Petiniot L, Uozumi N, Divanovic S, Traurnicht A, Bonkowski E, Kugathasan S, Karp CL, Denson LA (2010) Lipopolysaccharide exposure is linked to activation of the acute phase response and growth failure in pediatric Crohn's disease and murine colitis. Inflamm Bowel Dis 16: 856-869. doi: 10.1002/ibd.21132.

Peeters PH, Keinan-Boker L, van der Schouw YT, Grobbee DE (2003) Phytoestrogens and breast cancer risk. Review of the epidemiological evidence. Breast Cancer Res Treat 77: 171-183.

Pepels PP, Bonga SE, Balm PH (2004) Bacterial lipopolysaccharide (LPS) modulates corticotropin-releasing hormone (CRH) content and release in the brain of juvenile and adult tilapia (Oreochromis mossambicus; Teleostei) J Exp Biol 207: 4479-4488.

Plottel CS, Blaser MJ (2011) Microbiome and malignancy. Cell Host Microbe 10: 324-335. doi: 10.1016/j.chom.2011.10.003.

Poesen R, Meijers B, Evenepoel P (2013) The colon: an overlooked site for therapeutics in dialysis patients. Semin Dial 26: 323-332. doi: $10.1111 /$ sdi.12082.
Pomerantz DK, Pitelka V (1998) Nitric oxide is a mediator of the inhibitory effect of activated macrophages on production of androgen by the Leydig cell of the mouse. Endocrinology 139: 922-931.

Poutahidis T, Springer A, Levkovich T, Qi P, Varian BJ, Lakritz JR, Ibrahim YM, Chatzigiagkos A, Alm EJ, Erdman SE (2014) Probiotic microbes sustain youthful serum testosterone levels and testicular size in aging mice. ed. Schlatt S. PLoS One 9: e84877. doi: 10.1371/ journal.pone.0084877.

De Prada P, Setchell KD, Hylemon PB (1994) Purification and characterization of a novel 17 alpha-hydroxysteroid dehydrogenase from an intestinal Eubacterium sp. VPI 12708. I Lipid Res 35: 922-929.

Price JC, Bromfield JJ, Sheldon IM (2013) Pathogen-associated molecular patterns initiate inflammation and perturb the endocrine function of bovine granulosa cells from ovarian dominant follicles via TLR2 and TLR4 pathways. Endocrinology 154: 3377-3386. doi: 10.1210/en.2013-1102.

Priego T, Ibáñez de Cáceres I, Martín AI, Villanúa MA, López-Calderón A (2003) Endotoxin decreases serum IGFBP-3 and liver IGFBP-3 mRNA: comparison between Lewis and Wistar rats. Mol Cell Endocrinol 199: 23-28.

Ridlon JM, Ikegawa S, Alves JMP, Zhou B, Kobayashi A, Iida T, Mitamura K, Tanabe G, Serrano M, De Guzman A, Cooper P, Buck GA, Hylemon PB (2013) Clostridium scindens: a human gut microbe with a high potential to convert glucocorticoids into androgens. I Lipid Res 54: 2437-2449. doi: 10.1194/jlr.M038869.

Roumen RM, Frieling JT, van Tits HW, van der Vliet JA, Goris RJ (1993) Endotoxemia after major vascular operations. I V asc Surg 18: 853-857.

Rutgers M, Heusdens FA, Bonthuis F, de Herder WW, Hazenberg MP, Visser TJ (1989) Enterohepatic circulation of triiodothyronine (T3) in rats: importance of the microflora for the liberation and reabsorption of T3 from biliary T3 conjugates. Endocrinology 125: 2822-2830.

Schietroma M, Carlei F, Cappelli S, Amicucci G (2006) Intestinal permeability and systemic endotoxemia after laparotomic or laparoscopic cholecystectomy. Ann Surg 243: 359-363.

Schietroma M, Pessia B, Carlei F, Cecilia EM, Amicucci G (2013) Intestinal permeability, systemic endotoxemia, and bacterial translocation after open or laparoscopic resection for colon cancer: a prospective randomized study. Int J Colorectal Dis 28: 1651-1660. doi: 10.1007/s00384-013-1751-4.

Setchell KDR, Clerici C, Lephart ED, Cole SJ, Heenan C, Castellani D, Wolfe BE, Nechemias-Zimmer L, Brown NM, Lund TD, Handa RJ, Heubi JE (2005) S-equol, a potent ligand for estrogen receptor beta, is the exclusive enantiomeric form of the soy isoflavone metabolite produced by human intestinal bacterial flora. Am J Clin Nutr 81: 1072-1079.

Shimizu K, Muranaka Y, Fujimura R, Ishida H, Tazume S, Shimamura $\mathrm{T}$ (1998) Normalization of reproductive function in germfree mice following bacterial contamination. Exp Anim 47: 151-158.

Smith JL (1982) Sir Arbuthnot Lane, chronic intestinal stasis, and autointoxication. Ann Intern Med 96: 365-369.

Sohail MU, Ijaz A, Yousaf MS, Ashraf K, Zaneb H, Aleem M, Rehman H (2010) Alleviation of cyclic heat stress in broilers by dietary supplementation of mannan-oligosaccharide and Lactobacillus-based probiotic: dynamics of cortisol, thyroid hormones, cholesterol, C-reactive protein, and humoral immunity. Poult Sci 89: 1934-1938. doi: $10.3382 /$ ps.2010-00751.

Soory M (1995) Bacterial steroidogenesis by periodontal pathogens and the effect of bacterial enzymes on steroid conversions by human gingival fibroblasts in culture. J Periodontal Res 30: 124-131.

Sperandio V, Torres AG, Jarvis B, Nataro JP, Kaper JB (2003) Bacteria-host communication: the language of hormones. Proc Natl Acad Sci U S A 100: 8951-8956.

Stanley F, Samuels HH (1984) n-Butyrate effects thyroid hormone stimulation of prolactin production and mRNA levels in GH1 cells. J Biol Chem 259: 9768-9775.

Stárka L (2003) Epitestosterone. I Steroid Biochem Mol Biol 87: 27-34.

Storelli G, Defaye A, Erkosar B, Hols P, Royet J, Leulier F (2011) Lactobacillus plantarum promotes Drosophila systemic growth by modulating hormonal signals through TOR-dependent nutrient sensing. Cell Metab 14: 403-414. doi: 10.1016/j.cmet.2011.07.012.

Sudo N, Chida Y, Aiba Y, Sonoda J, Oyama N, Yu X-N, Kubo C, Koga Y (2004) Postnatal microbial colonization programs the hypothalamic-pituitary-adrenal system for stress response in mice. $J$ Physiol 558: 263-275.

Taghavi SA, Ashrafi M, Mehdizadeh M, Karimian L, Joghataie MT, Aflatoonian R (2014) Toll-like receptors expression in follicular cells of patients with poor ovarian response. Int J Fertil Steril 8: 183-192.

Takahashi M, Kimura H, Watanabe K (2002) Helicobacter pylori infection in patients with idiopathic short stature. Pediatr Int 44: 277-280.

Takumi N, Shirakawa H, Ohsaki Y, Ito A, Watanabe T, Giriwono PE, Sato T, Komai M (2011) Dietary vitamin $\mathrm{K}$ alleviates the reduction in testosterone production induced by lipopolysaccharide administration in rat testis. Food Funct 2: 406-411. doi: 10.1039/c1fo10058k 
Toh S, Mitchell AA, Anderka M, de Jong-van den Berg LTW, Hernández-Díaz S (2011) Antibiotics and oral contraceptive failure - a case-crossover study. Contraception 83: 418-425. doi: 10.1016/j.contraception.2010.08.020.

Tolhurst G, Heffron H, Lam YS, Parker HE, Habib AM, Diakogiannaki E, Cameron J, Grosse J, Reimann F, Gribble FM (2012) Short-chain fatty acids stimulate glucagon-like peptide-1 secretion via the G-protein-coupled receptor FFAR2. Diabetes 61: 364-371. doi: $10.2337 / \mathrm{db} 11-1019$.

Touillaud MS, Thiébaut ACM, Fournier A, Niravong M, Boutron-Ruault M-C, Clavel-Chapelon F (2007) Dietary lignan intake and postmenopausal breast cancer risk by estrogen and progesterone receptor status. J Natl Cancer Inst 99: 475-486.

Tsavkelova EA, Klimova SI, Cherdyntseva TA, Netrusov AI (2006) Hormones and hormone-like substances of microorganisms: a review. Prikl Biokhim Mikrobiol 42: 261-268.

Ukai M, Mitsuma T (1978) Plasma triiodothyronine, thyroxine and thyrotrophin levels in germfree rats. Experientia 34: 1095-1096.

Ursell LK, Metcalf JL, Parfrey LW, Knight R (2012) Defining the human microbiome. Nutr Rev 70 (Suppl 1): S38-44. doi: 10.1111/j.1753-4887.2012.00493.x.

Varian BJ, Poutahidis T, Levkovich T, Ibrahim YM, Lakritz JR, Chatzigiagkos A, Scherer-Hoock A, Alm EJ, Erdman SE (2014) Beneficial bacteria stimulate youthful thyroid gland activity. J Obes Weight Loss Ther 04: 220. doi: 10.4172/2165-7904.1000220

Vélez ML, Costamagna E, Kimura ET, Fozzatti L, Pellizas CG, Montesinos MM, Lucero AM, Coleoni AH, Santisteban P, Masini-Repiso AM (2006) Bacterial lipopolysaccharide stimulates the thyrotropin-dependent thyroglobulin gene expression at the transcriptional level by involving the transcription factors thyroid transcription factor-1 and paired box domain transcription factor 8. Endocrinology 147: $3260-3275$.

Vendt N, Grünberg H, Tuure T, Malminiemi O, Wuolijoki E, Tillmann V, Sepp E, Korpela R (2006) Growth during the first 6 months of life in infants using formula enriched with Lactobacillus rhamnosus GG: double-blind, randomized trial. J Hum Nutr Diet 19: 51-58.

Veronikis IE, Alex S, Fang SL, Wright G, Wu SY, Chanoine JP, Emerson CH, Braverman LE (1996) Influence of thyroidectomy on thyroxine metabolism and turnover rate in rats. Eur $J$ Endocrinol 134: 519-523.

Vijayakumar A, Novosyadlyy R, Wu Y, Yakar S, LeRoith D (2010) Biological effects of growth hormone on carbohydrate and lipid metabolism. Growth Horm IGF Res 20: 1-7. doi: 10.1016/j. ghir.2009.09.002.

Vought RL, Brown FA, Sibinovic KH, McDaniel EG (1972) Effect of changing intestinal bacterial flora on thyroid function in the rat. Horm Metab Res 4: 43-47.

Vrieze A, Holleman F, Zoetendal EG, de Vos WM, Hoekstra JBL, Nieuwdorp M (2010) The environment within: how gut microbiota may influence metabolism and body composition. Diabetologia 53: 606-613. doi: 10.1007/s00125-010-1662-7.

Wang C-Z, Ma X-Q, Yang D-H, Guo Z-R, Liu G-R, Zhao G-X, Tang J, Zhang Y-N, Ma M, Cai S-Q, Ku B-S, Liu S-L (2010) Production of enterodiol from defatted flaxseeds through biotransformation by human intestinal bacteria. BMC Microbiol 10: 115. doi: 10.1186/14712180-10-115.

Wang P, Li N, Li J-S (2002a) Mechanism of growth hormone insensitivity induced by endotoxin. Acta Pharmacol Sin 23: 16-22.

Wang P, Li N, Li J-S, Li W-Q (2002b) The role of endotoxin, TNF-alpha, and IL-6 in inducing the state of growth hormone insensitivity. World J Gastroenterol 8: 531-536.

Wang X, Jiang J, Warram J, Baumann G, Gan Y, Menon RK, Denson LA, Zinn KR, Frank SJ (2008) Endotoxin-induced proteolytic reduction in hepatic growth hormone $(\mathrm{GH})$ receptor: a novel mechanism for GH insensitivity. Mol Endocrinol 22: 1427-1437. doi: 10.1210/me.2007-0561.

Warner MH, Beckett GJ (2010) Mechanisms behind the non-thyroidal illness syndrome: an update. J Endocrinol 205: 1-13. doi: 10.1677/ JOE-09-0412.
Watanabe M, Houten SM, Mataki C, Christoffolete MA, Kim BW, Sato H, Messaddeq N, Harney JW, Ezaki O, Kodama T, Schoonjans K, Bianco AC, Auwerx J (2006) Bile acids induce energy expenditure by promoting intracellular thyroid hormone activation. Nature 439: 484-489.

Weisberg E (1999) Interactions between oral contraceptives and antifungals/antibacterials. Is contraceptive failure the result? Clin Pharmacokinet 36: 309-313.

Wells JE, Hylemon PB (2000) Identification and characterization of a bile acid 7alpha-dehydroxylation operon in Clostridium sp. strain TO-931, a highly active 7alpha-dehydroxylating strain isolated from human feces. Appl Environ Microbiol 66: 1107-1113.

Van de Wiele T, Vanhaecke L, Boeckaert C, Peru K, Headley J, Verstraete W, Siciliano S (2005) Human colon microbiota transform polycyclic aromatic hydrocarbons to estrogenic metabolites. Environ Health Perspect 113: 6-10.

Williams EJ, Sibley K, Miller AN, Lane EA, Fishwick J, Nash DM, Herath S, England GCW, Dobson H, Sheldon IM (2008) The effect of Escherichia coli lipopolysaccharide and tumour necrosis factor alpha on ovarian function. Am J Reprod Immunol 60: 462-473.

Winnall WR, Muir JA, Hedger MP (2011) Differential responses of epithelial Sertoli cells of the rat testis to Toll-like receptor 2 and 4 ligands: implications for studies of testicular inflammation using bacterial lipopolysaccharides. Innate Immun 17: 123-136. doi: $10.1177 / 1753425909354764$.

Winter J, Morris GN, O'Rourke-Locascio S, Bokkenheuser VD, Mosbach EH, Cohen BI, Hylemon PB (1984a) Mode of action of steroid desmolase and reductases synthesized by Clostridium "scindens" (formerly Clostridium strain 19) J Lipid Res 25: 1124-1131.

Winter J, O'Rourke-Locascio S, Bokkenheuser VD, Mosbach EH, Cohen BI (1984b) Reduction of 17-keto steroids by anaerobic microorganisms isolated from human fecal flora. Biochim Biophys Acta 795: 208-211.

Wostmann BS (1973) Intestinal bile acids and cholesterol absorption in the germfree rat. I Nutr 103: 982-990.

Wu S-Y, Green WL, Huang W-S, Hays MT, Chopra IJ (2005) Alternate pathways of thyroid hormone metabolism. Thyroid 15: 943-958.

Yee S, Burdock GA, Kurata Y, Enomoto Y, Narumi K, Hamada S, Itoh T, Shimomura Y, Ueno T (2008) Acute and subchronic toxicity and genotoxicity of SE5-OH, an equol-rich product produced by Lactococcus garvieae. Food Chem Toxicol 46: 2713-2720. doi: 10.1016/j. fct.2008.04.026.

Yeo S-K, Liong M-T (2010) Angiotensin I-converting enzyme inhibitory activity and bioconversion of isoflavones by probiotics in soymilk supplemented with prebiotics. Int J Food Sci Nutr 61: 161-181. doi: 10.3109/09637480903348122.

Young JC, Kenyon EM, Calabrese EJ (1990) Inhibition of beta-glucuronidase in human urine by ascorbic acid. Hum Exp Toxicol 9: 165-170.

Yu J, Koenig RJ (2000) Regulation of hepatocyte thyroxine 5'-deiodinase by $\mathrm{T} 3$ and nuclear receptor coactivators as a model of the sick euthyroid syndrome. I Biol Chem 275: 38296-38301.

Yurkovetskiy L, Burrows M, Khan AA, Graham L, Volchkov P, Becker L, Antonopoulos D, Umesaki Y, Chervonsky A V (2013) Gender bias in autoimmunity is influenced by microbiota. Immunity 39: 400-412. doi: 10.1016/j.immuni.2013.08.013.

Zaineddin AK, Buck K, Vrieling A, Heinz J, Flesch-Janys D, Linseisen J, Chang-Claude J (2012) The association between dietary lignans, phytoestrogen-rich foods, and fiber intake and postmenopausal breast cancer risk: a German case-control study. Nutr Cancer 64: 652-665. doi: 10.1080/01635581.2012.683227.

Zimomra ZR, Porterfield VM, Camp RM, Johnson JD (2011) Time-dependent mediators of HPA axis activation following live Escherichia coli. Am J Physiol Regul Integr Comp Physiol 301: R1648-57. doi: 10.1152/ajpregu.00301.2011.

Zółtaszek R, Hanausek M, Kiliańska ZM, Walaszek Z (2008) The biological role of D-glucaric acid and its derivatives: potential use in medicine. Postepy Hig Med Dosw (Online) 62: 451-462. 